Cilt: 19, Say1: 2, 2021, ss. 446-470 ｜ Volume: 19, Issue: 2, 2020, pp. 446-470

\title{
Kelâm'da Zanla İstidlâlin İmkân ve Değeri
}

The Availability of Conjectural Knowledge and Its Epistemic Value in Kalam

\section{Abdulnasır SÜT}

Doç. Dr., Bingöl Üniversitesi, İslami İlimler Fakültesi, Bingöl/Türkiye Associate Professor Dr., Bingöl University, Faculty of Islamic Studies, Bingöl/Türkiye nasr_12@hotmail.com | orcid.org/0000-0001-5971-0611 | ror.org/03hx84x94

\author{
Makale Bilgisi Article Information \\ Makale Türü Article Type \\ Araştırma Makalesi Research Article \\ Geliş Tarihi Date Recieved \\ 20 Ağustos 202120 August 2021 \\ Kabul Tarihi Date Accepted \\ 28 Aralı 2021 28 December 2021 \\ Yayın Tarihi Date Published \\ 31 Aralı 202131 December 2021 \\ Intihal Plagiarism
}

Bu makale, iTenticate yazılımı ile taranmıştır. İntihal This article has been scanned with iTenticate tespit edilmemiştir. software. No plagiarism detected.

\section{Etik Beyan Ethical Statement}

Bu çalışmanın hazırlanma sürecinde bilimsel ve etik ilkelere uyulduğu ve yararlanılan tüm çalışmaların kaynakçada belirtildiği beyan olunur (Abdulnasır It is declared that scientific and ethical principles have been followed while carrying out and writing this study and that all the sources used have been Süt). properly cited (Abdulnasır Süt).

CC BY-NC-ND 4.0 lisansı ile lisanslanmıştır. Licensed under CC BY-NC-ND 4.0 license.

66 


\section{Öz}

Kelamcılar arasında zannî bilginin dinin temel itikadî ilkelerinin tespitinde belirleyici ve bağlayıcı olarak esas alınamayacağı görüşü hâkimdir. Bununla birlikte kesinlik ifade eden bilginin hangi kaynaklardan ve nasıl elde edileceği ve hangi bilgi türlerinin kattî olduğu hususu yoğun bir şekilde tartışılmıştır. Kat'î ve zannî bilgi, delile dayanma açısından ortak bir noktada buluşmaktadır. Zannî bilgi, kesinlik ifade etmeyen aklî ve/veya naklî delille elde edilmektedir. Zan, mahiyet açısından vehim, şek, itikat ve ilim kavramlarıyla ilişkiliyken değer açısından ise daha çok ilim ve itikat kavramlarına yakın durmaktadır. Bir bilgi/hüküm zannîlik açısından derecelendirmeye tabi tutulduğunda, doğruluk tarafı ağır basıyorsa zan, zayıf kalıyorsa vehim vasfını almaktadır. Doğru olup-olmadığı eşit düzeyde ise bu hüküm şek ismiyle anılmaktadır. Aklî delilden elde edilen bilgi/hüküm sabit, değişmez ve uygunluk yönünden başka şekilde olmasına imkân vermeyecek bir kesinlikte olması halinde kat'î bilgi adını alır. Kelâmcılar ulûhiyet bahislerinde (Allah'ın varlığı, birliği, kadim oluşu, sıfatların zat ile ilişkisi, Allah'ın âlemle ilişkisi, âlemin hadis oluşu gibi), nübüvvetin imkânı ve ispatında bu tür bilgi sağlayan kıyas, istikra, sebr ve taksim gibi aklî istidlal yöntemlerine başvurmuşlardır. Delil kesin bilgi sağlamıyorsa zan ifade eder, bu delil ayrıca zannî delil, emare olarak da nitelenir. Kelâmcılar aklî açıdan zan ifade eden meşhûrât, müsellemât, makbûlât ve temsilden oluşan bilgi türlerinin dinin temel itikadî konularını temellendirmekten ziyade muhataplarını ikna etmek ve muarızlarını ilzâm etmek için kullanmışlardır. Kelâmcılar temel itikadî konuların başında yer alan ulûhiyet bahislerinde daha çok aklî delilleri kullanmakla birlikte dinin temel konularını belirleyen nakle de önemli ölçüde yer vermişlerdir. Bu bağlamda kelâmcılar sübût ve delalet açısından kat'̂̂ olan naklî delili bağlayıcı ve belirleyici kabul etmişlerdir. Nitekim dinin temel itikadî ilkeleri sonuç itibariyle bu tür naklî delillere dayanmaktadır. Bununla birlikte kelâmcılar her ne kadar sübût ve delâlet açısından kat î olmayan haber-i vâhid gibi delilleri bağlayıcı kabul etmemişlerse de bazı semî̀ konularda bu türden delillerle istidlâlde bulunmuşlardır. Bu perspektiften hareket eden kelâmcılar ahiret ahvali kapsamında yer alan kabir azabı, mizan, şefaat, sırat gibi semî̂ konuları aklî istidlalden ziyade naklî delille temellendirmeye çalışmışlardır. Bu çalışma klasik kelâmî kaynaklarda tartışılagelen zannî bilginin istidlal değerini ve kullanım alanını konu edinmiş ve elde edilen veriler nitel bir yöntemle farklı açılardan değerlendirmeye tabi tutulmuştur. Bu cümleden olmak üzere zannî bilginin bazı tâli itikadî konularda geçerli olduğu ve kelâmda zannın istidlal değerinin olmadığı yönündeki söylemin mutlak olmadığı sonucuna varılmıştır. Anahtar Kelimeler: Kelâm, İlim, Yakîn, İtikad, Zan, Delil.

\section{Abstract}

There is a prevailing opinion that conjectural knowledge (zann) cannot be taken as a basis in determining the fundamental theological principles among the theologians. However, from which sources and how to obtain certainty (yaqin) and which types of knowledge are definitive ( $q a t^{i} i \bar{i}$ have been discussed extensively. Certain and conjectural knowledge meet at a common point in terms of relying on evidence. Conjectural knowledge obtained via reasoning and/or religious scripture that do not express certainty. While conjectural knowledge has been essentially related to the concepts of estimation, doubt, belief and knowledge, by its in term of value, it is stands closer to the concepts of knowledge and belief. Conjectural knowledge contains different degrees of certainty. When it is chosen to be more certain, it is considered as a valid conjecture, when it is disregarded, it is considered as erroneous conjecture. If there is no choice for its certainty, then it is called doubt (shakk). If the information/judgment obtained through reasoning becomes fixed, unchangeable and in a coherence that does not allow it to be otherwise, then it is called definitive ( $q a t^{t} i$ ) knowledge. To achieve that, theologians generally used methods of argumentations like syllogism, induction, exhaustive investigation and disjunction (al-sabr wa'l-taqsim) to provide such knowledge about divinity and prophethood. Theologians have used conjectural knowledge, which are based on endoxic (mashhūrāt), already granted (musallamāt) and acceptance of authority (maqbūlāt), in their dialectics to persuade their discussants, rather than to justify the fundamental theological issues of religion. While theologians mostly use rational proofs in theological issues, they also gave significant place to the scriptural narrative that determines the creed. In this context, theologians accepted the narrated evidence as binding and decisive, as long as it is certain in terms of both authenticity and implication. Ultimately, the fundamental theological principles of religion are based on these narrative evidences. Although the theologians do not accept single reports (khabar al-wahid) for their questionable authenticity, they also made inferences regarding subjects of traditions (samiyyāt). Acting from this perspective, theologians tried to justify with narrative evidence rather than rational arguments on these issues such as torment in grave, intercession (shafätah) and sirât, which are mostly matters of eschatology and the unseen (ghayb). Finally, it has been concluded that the conjectural knowledge is still valid in some secondary theological issues and the assumption that the conjectural knowledge has no deduction value in theology is not absolute.

Keywords: Kalam, Knowledge, Certainty, Belief, Conjecture, Argument. 


\section{Giriş}

Bilginin Müslüman kelâmında ele alınan temel konular arasında yer almasının başat nedeni, doğru bir inanca ulaşmanın kesin bir bilgiye dayanmasıdır ki bu tür bir bilginin elde edilmesi de ancak onu oluşturan kaynaklar ve bunların kesinlik değerinin tespitiyle mümkündür. $\mathrm{Bu}$ bağlamda hangi bilgi kaynaklarının ve hangi yöntemlerin kesin bilgi ve inanç sağladığına ilişkin kelâmda var olan zengin literatür kelâmî epistemoloji açısından oldukça önemlidir.

Kelâmı oluşturan konuların başında dinin asli konularını teşkil eden itikadî mevzular olması hasebiyle bu mevzuların temellendirilmesinin kesinlik ifade eden bilgiye dayandırılması kelâmcılar tarafından temel konular arasında sayılmıștır. Bu kesinliğin nasıl sağlanacağı hususunda teorik ve ilkesel düzeyde kelâmcılar arasında bir görüş birliği olduğu da söylenebilir. Kelâmcılar, kesin deliller (yakīni deliller) aracılığıyla itikadî hükümlerin temellendirilmesinin gerekli olduğunu ilkesel olarak kabul etmişlerdir. ${ }^{1}$ Onlara göre "itikadî konularda zanniyyâta itibar edilmez." Ancak hem Ehl-i sünnet hem de Mu'tezilî kelâmcllarının nazari düzlemde kabul ettikleri "itikadî hükümler, sübûtu ve delâleti kat'î delille belirlenir" veya "itikadda zannî delil ile istidlalde bulunulmaz" şeklindeki söylemlerine itikadî ilkelerin belirlenmesinde ve temellendirilmesinde hakkıyla riayet edip-etmedikleri tartışmaya değer bir konudur. Kelâmî literatüre bakıldığında esasın belirlenmesinde kabul edilen usul, belirlendiği şekliyle uygulanmış mıdır? Hangi istidlal yöntemlerinin kesin bilgi sağladı̆̆ı ve hangi bilgilerin yakini olduğu konusunda bir görüş birliği var mıdır? Zannın hiçbir şekilde esas alınamayacağı -akîde/itikad gibi- özel alanlar var mıdır? Bir başka ifadeyle zannî bilgiler itikadî hükümlerin tespit edilmesi ve bağlayıcı kabul edilmesinde kullanılmış mıdır? Çalışmada bu konularda kelâmcıların görüşleri üzerinde durularak bazı değerlendirmeler yapılacaktır. Ittikadî konularının belirlenmesinde ve delillendirilmesinde zannî bilginin değerini ve rolünü ortaya koymak kelâmî ekollerin niçin farklı itikadî görüşlere vardıklarını da kısmen açıklamış olacaktır.

Bir bilginin/hükmün doğrulanma durumuna ve kişinin mutmain olma seviyesine, diğer bir deyişle bilginin kesinlik derecesine bağlı olarak üç hali/hükmü olduğu söylenebilir. Bilginin kesinlik değerine ve derecesine bağlı olan bu üç hüküm; kesin (yakīn), itikad (itikad-i câzim) ve zan (zannî) şeklindedir. Bilginin kesinlik vasfina halel getiren unutma, yanılma ve karıştırma gibi durumların ilişmediği bilgi yakin/kat î kavramıla ifade edilmiştir. Bu tür bir bilgi, hüküm verenin zihninde kesinlik taşıdığı gibi vakıaya da mutabıktır. Böyle bir bilginin hilafı/zıddı mümkün değildir. İkinci hal ise kesin olduğuna inanmakla beraber sonraki süreçte daha güçlü bir delil nedeniyle farklı inanmaya açık olan hüküm, itikad-i câzim kavramıyla ifade edilmiştir. Bu durumda bulunan kişi, verdiği hükümde hiçbir şüphe duymayacak ve çelişiğini hissetmeyecek olsa da bu hükümde duraksama ve yanılma ihtimali söz konusu olabilmektedir. Üçüncü hal ise

Sa‘deddîn et-Teftâzânî, el-Makāsıd, çev. İrfan Eyibil (İstanbul: Türkiye Yazma Eserler Kurumu Başkanlı̆̆ı, 2019), 9293. Kelâm ilminin tanımı yapılırken kat'i delil vurgusu zannî delille itikadın inşa edilemeyeceğini vurgulamak için yapilmaktadır.

Fahreddin Muhammed b. Ömer er-Râzî, et-Tefsirül-Kebîr (Kahire: Daru'l-hadîs, 2012), 1/375; Sa'deddîn et-Teftâzânî, Şerhu'l-Makāsıld (Lübnan: Darü'l-Kütübi'l-i̇lmiyye, 2011), 1/29. 
bilgiyi/hükmü kabul etmekle beraber çelişiğine imkân veren durumlardır ki bu da genel olarak zan kavramiyla ifade edilmiştir. ${ }^{3}$

Şüphesiz zan, insanoğlunun bilişsel süreçlerinin en önemli unsurlarından biridir. Müslüman düşüncesinin gelişim ve kurumsallaşmasında zannî bilgiler önemli bir yer tutmaktadır. Diğer bir deyişle dinî ve fikri literatürün teşekkülünde zannî bilginin işlevi ve önemi büyüktür. Düşünce; sanı ve kanı üzerine inşa edilen bir zihni faaliyettir. Bugünkü bilimsel faaliyet için kullanılan varsayım, sav, tez, hipotez ve teori gibi kavramlar ön kabule bir başka deyişle zanna dayandığı gibi Müslüman düşüncesinin gelişiminin temel kavramları olan nazar, rey, içtihat, kıyas, tevil ve tefsir kavramları da zannîlik taşıyan bilişsel süreçleri ifade eden kavramlardır. Bugün elimizdeki düşünsel mirasın önemli bir kısmı zannîlik taşıyan bu aklî süreçler neticesinde oluşan bilgilerden meydana gelmektedir. Ekollerin ve âlimlerin görüş farklılıkları onların usullerine ve bu usullere dayanan yorum farklarına bağlı olarak oluşmaktadır. Zaten Müslüman düşünce geleneğinde zannî bilginin şer'î-amelî alanda bağlayıcı olduğu konusunda bir fikir birlikteliği vardır. ${ }^{4}$

Zan; kuşkulanmak, kesinleşmemiş kanaat veya bilgi için kullanılan bir kavramdır. Râgıp elİsfahânî zannı; "bir emâreden hâsıl olan kanaat" şeklinde tanımlamakta, şayet emâre/karine güçlü olursa bu durumda zannın bilgi, zayıf olursa vehim olacağını ifade etmektedir. ${ }^{5}$ Alî $b$. Muhammed b. Alî el-Cürcânî (ö. 816/1413) zannı "nakizi/çelişiği mümkün olmakla beraber doğruluk tarafi ağır basan kanaat (itikad), ${ }^{6}$ şeklinde tarif ederken Âmidî (ö.631/1233), "nefisteki iki karşılt mümkünden birinin diğerine tercih edilmesi" şeklinde tanımlamaktadır. Zannın, yakīn, şek ve vehmi de kapsayıp-kapsamadığı konusunda farklı görüşler mevcuttur. ${ }^{8}$ Cürcânî, zannın hem doğruluğu kuşkulu hem de kesin kabul edilen bilgiyi ifade ettiğini söylemiştir. ${ }^{9}$ Zannın geniş olan bu anlam yelpazesi Kur'an-1 Kerim'den de çıkarılabilir. Bazı ayetlerde zan kavramı töhmet, su-i zan, cehalet gibi olumsuz, bazı ayetlerde ise kanaat, iman ve yakin gibi olumlu anlamda kullanılmıştır. ${ }^{10}$ Ancak Fahreddin Râzî (ö. 606/1210) bir hükme, doğruluk tarafı ağır basıyorsa zan, zayıf kalıyorsa vehim, eşit durumda ise şek adını vermekte ve bu bilgi mertebeleri arasında zannîlik yönünden bir derecelendirme yapmaktadır. ${ }^{11}$ Şüphesiz zan kavramının epistemolojik değerinin yanında ahlakî bağlamda önemli bir kavram olduğu da açıktır. Kişinin su-i zan veya hüsnü zan sahibi olmasının, onun düşünce, duygu ve fillerinde önemli bir etkiye sahip olacağı bilinmektedir.

Ebu Hamid Gazzâlî, Mustasfa, çev. Yunus Apaydın (Kayseri: Rey Yayıncllık, 1994), 1/58; Mustafa Çağrıc1, "Zanniyat” (İstanbul: Türkiye Diyanet Vakfi İslâm Ansiklopedisi, 2013), 44/124.

4 Bedreddin ez-Zerkeşî, Luktatü'l-'aclân, thk. Muhammed Cemaleddin el-Kasimi ed-Dımeşkî (Kahire: Medresetü Valideti Abbasi'l-Evvel, 1908), 61.

Ragıp el-İsfahânî, el-Müfredât fi elfâzi'l-Kur'an, ed. Safvan Adnan Davûdi (Dımaşk: Darü'l-Kalem, 2009), 539.

Seyyid Şerif Cürcâni, Kitabü't-Ta'rîfât, thk. Muhammed Abdurrahman el-Mer'aşlî (Beyrut: Daru'n-Nefâis, 2007), 219.

Seyfuddin Âmidî, Ebkârü'l-efkâr, ed. Ahmed Ferid Mezidi (Beyrut: Daru'l-Kutubü'l-ïlmiyye, 2003), 1/57.

8 M. Muaz Mustafa el-Hın, el-Kat'î ve'z-zannî fi's-sübût ve'd-delâle 'inde'l-usûliyyîn (Dımaşk: Darü'l-Kelimi't-Tayyib, 2007), 76-77.

Cürcâni, Ta'rîfât, 219.

el-İsfahânî, el-Müfredât, 539-540.

Fahreddin Muhammed b. Ömer er-Râzî, Me'âlimü usûli'd-dîn: Kelâm ỉlminin Esasları, çev. Muhammet Altaytaş (İstanbul: Türkiye Yazma Eserler Kurumu Başkanlığı, 2019), 44. 
Müslüman düşünürler, bilginin zannîlik derecesine bağlı olarak farklı türlerinin olduğuna dikkat çekmişlerdir. Bu zan türleri içerisinde kesinliğe yakın olanı en açık zan, şekke yakın olanı en gizli zan ve bu iki derece arasında yer alanı da orta zan şeklinde tasnif etmişlerdir. Yine kaynaklarda kesin bilgiye yakın olana zann-1 galip, şekke yakın olana da zann-1 âdî şeklinde nitelemeler mevcuttur. Bu, bilginin doğruluğuna olan inanç seviyesinin artma, kalbinin sükûn bulma ve tasdik etme keyfiyetine/oranına bağlı olarak tahakkuk etmektedir. ${ }^{12}$ Zannın doğruluk derecesinin artması, bilginin doğruluğunu gösteren emârelerin artmasına bağlıdır. ${ }^{13}$

Bilginin kesinlik derecesini belirleyen unsur, delildir. Bazen hüccet, burhan, beyan ve sultan kavramları da delil manasında kullanılmıştır. ${ }^{14}$ Bilginin kat î veya zannî oluşunu belirleyen etmen, aklî ve naklî delilin kat'îliği ya da zanniliğidir. Delil de kapsam (icmâlî/tafsîlî), dayanak (aklî/naklî̀) sübut ve delâlet (kat'î/zannî) açısından taksim edilmiştir. ${ }^{15}$ Lügatte yol gösterici (mürşid) manasında olan delil, istılahta onu bilmekle başka bir şeyi bilmeyi gerekli kılan şey manasındadır. ${ }^{16}$ Genel olarak kelâmcılar aklî delilde öncülleri kesin bilgilerden oluşan kıyas ile naklî delilde delâleti kat'î olan kitap, mütevâtir haber ve icmâdan oluşan delillerin kat'î bilgi sağladığı görüşünde olmuşlardır. ${ }^{17}$ İcmâ delilinin inanç konularına nasıl taalluk ettiği yönünde bir uzlaşı ve detaylı bir bilgi yoksa da bununla icmânın sağladığı bilginin kesinlik ifade ettiği vurgulanmak istenmiştir.

Kelâmcılar kesin bilgi ile zannî bilgiye ulaşma aracını farklı nitelemişlerdir. Onlara göre "delil ile ulaşılan hükme ilim, emâre ile ulaşılan hükme de zan" denilmektedir. ${ }^{18}$ Fahreddin Râzî bu hususu şöyle ifade etmektedir: Delil, medlûlün varlığının bilgisini kesin düzeyde, emâre ise medlûlün varlığının bilgisini zannî düzeyde ifade eder. ${ }^{19}$ Yukarıda da ifade edildiği üzere İsfahânî bu ayrımı emârenin/delilin güçlü ve zayıf oluşuna bağlamaktadır. Ona göre emâre güçlü olursa bilgi, zayıf olursa zan olur. Kelâmcılar teorik düzeyde bilgiyi sağlayanın delil, zannî bilgiyi sağlayanın emâre olduğunu ifade etmekle beraber eserlerinde genellikle her ikisi için de delil kavramını (kat'î veya zannî delil) kullanmışlardır. Mukallidin imanının geçerliliğinin tartışılması da taklidin zan içerip içermemesinden kaynaklanmaktadır. ${ }^{20}$

İslam düşüncesindeki ilmi disiplinlerde yakīn kavramı bilgi ve inançta kesinliği ifade eden bir kavramdır. Nitekim Cürcânî yakini sözlükte "beraberinde şüphe olmayan kesin ilim"; 1stılahta ise "bir şeyin vakıaya uygun, değişmesi ve başka şekilde düşünülmesi mümkün olmayacak şekilde itikat etmektir" biçiminde tanımlamaktadır. ${ }^{21}$ İsfahânî yakīni; marifet, dirayet ve benzerlerinin üstünde

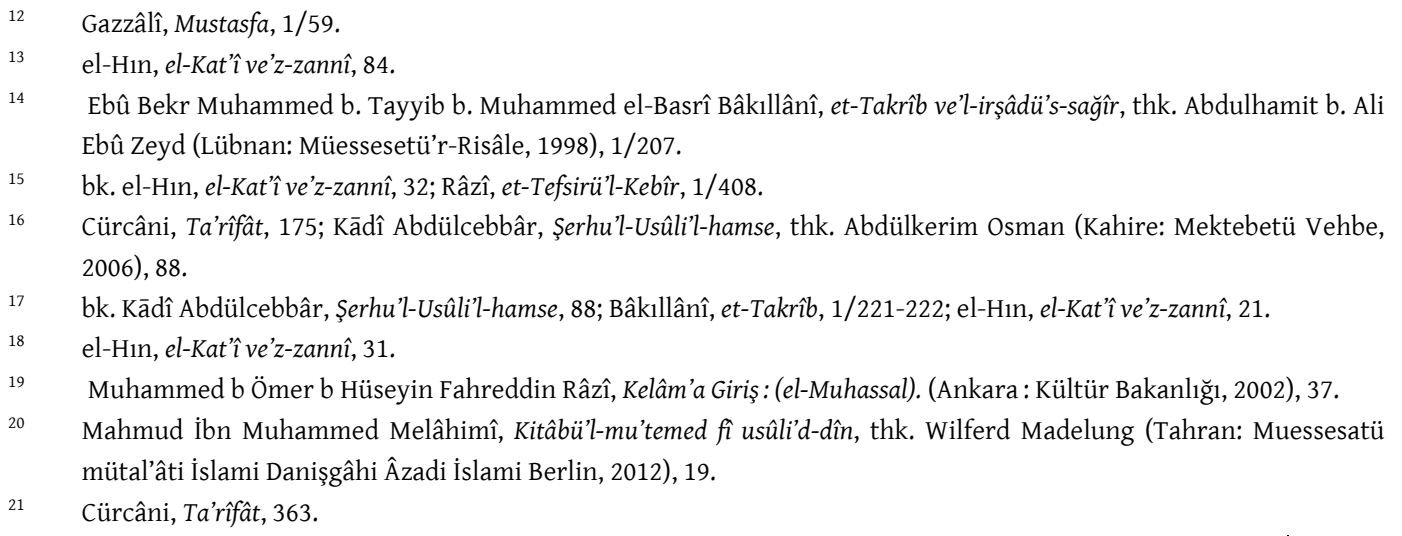


bir bilme sıfatı olarak nitelemekte ve "hükmün sabit olmasıyla zihnin sükûna ermesi"22 şeklinde tarif etmektedir. Yakinn ile bilgi arasında zorunlu bir ilişki mevcuttur. Yakīn şüphenin, bilgi cehaletin zıddı olarak ele alınmışsa da yakīn kavramı hem kesinlik ifade eden bilgi hem de inanç için kullanılmaktadır. Bilginin tanımlarından biri olan "anlamlar arasında çelişiğine ihtimal kalmayacak şekilde ayrım gerektiren bir sıfattır"23 şeklindeki tanım, kesin olmayan bilgi türlerini dışarda bırakmaktadır. Kelâmcılar genelde yakīn kavramını kesinliği ifade etmek için kullanmışlardır. İnancın yakīn derecesine ulaşması için şüphe, zan, cehalet ve taklit gibi doğru veya yanlış olma ihtimallerinden arındırılması gerektiğine dikkat çekmişlerdir. Fahreddin Râzî, Teftâzânî (ö. 792/1390) ve Cürcânî gibi kelâmcılar da yakīni, şüpheyi barındırmayan bilgi olarak tanımlamıştır. ${ }^{24}$ Bilgi dışındaki bilme biçimlerinde farklı seviyede de olsa tam, net ve kesin olarak bil(e)meme durumu söz konusudur. Cüveynî (ö. 478/1085) cehalet, şek ve zannı kesinlik ifade etmemeleri açısından bilginin zıddı olarak da ele almaktadır. ${ }^{25}$ Seyfeddin Âmidî bilginin zıddı olarak cehalet, şek, zan, gaflet, zühul, uyku, nazar ve ölümü saymaktadır. ${ }^{26}$ Bunların hiçbirisinin bilgiyle birleşmesi mümkün olmadığından bilgi gibi kesin olma vasfi taşımaz.

Kelâmî epistemolojide zannın epistemik değeri ve kurucu/inşâi yönü hakkında doğru bir değerlendirme yapabilmek için zan, itikad ve ilim kavramlarının birbirleriyle ilişkisi konusunda bir değerlendirme yapmak gerekir. Bu değerlendirmeyi yapmak, zannî bilginin kelâmdaki işlevi ve değeri konusunun anlaşılması açısından önem arz etmektedir.

\section{Zan-İtikad-ílim İlişkisi}

Zan, itikad ve ilim (kesin bilgi) arasındaki ilişkiyi ve etkileşimi görmek, zannın epistemik değerini daha anlaşılır kılacaktır. Hem zan hem itikad hem de ilimde idrak ve tasdik söz konusudur. Ancak idrak veya tasdikin vakıaya uygunluğu, doğruluğu ve dayandığı delil yönünden farklı durumları mevcuttur. Kat'î delile dayanan, vakıaya uygun ve doğruluğu kesin olan idrak ve tasdik ilimdir. Şekkin ortadan kalkmasıyla zihnin ve kalbin itminanına dayanan tasdik ise itikattır. Zanda ise bir hükümde bulunmakla beraber kat'î delile dayanmaması nedeniyle vakıaya uygunluk yönünden bir kesinlik bulunmamaktadır. ${ }^{27}$

Kelâmî epistemolojide merkezi bir role sahip olan nazar kavramı, kat'îlik ve zannîlik açısından farklı değerlendirmelere konu olmuştur. Nazarın tanımı "kendisiyle bilgi ya da zan elde edilmek istenen fikir" şeklinde yapılmıştır. ${ }^{28}$ Kelâmcıların nazar üzerinde önemle durmalarının temel nedeni, başta ulûhiyet ve nübüvvet gibi dini konuların ispatının yanında güvenilir bilgi elde etme imkânının ancak nazarla gerçekleşebileceğini savunmalarıdır. Onlar Allah'ın bilinmesi ve bununla ilgili hususları nazara dayandırmaktadırlar. ${ }^{29}$ Kelâmcılara göre eşyanın varllğını ve temel itikadî hükümlerini bilmenin en önemli aracı nazardır. Cüveynî nazarı, bilgiyi arama ve

22 el-i̇sfahânî, el-Müfredât, 892.

23 Teftâzânî, el-Makāsld, 98.

24 Osman Demir, “Yakīn” (İstanbul: Türkiye Diyanet Vakfi İslâm Ansiklopedisi, 2013), 43/271.

25 İmâmü'l-Haremeyn Ebü'l-Meâlî Rüknüddîn Abdülmelik b Abdullâh b Yûsuf Cüveynî, el-Irşâd ila kavâtii'l-edilleti fî usûli'l-i'tikād (Kahire : Mektebetü'l-Hanci, 1950), 14-15.

26 Ayrıntılı bilgi için bk. Âmidî, Ebkârü'l-efkâr, 1/52-61.

27 el-Hın, el-Kat'̂̀ ve'z-zannî, 58-59.

28 Teftâzânî, el-Makāsıd, 106.

29 Muhammed Hüseyni ez-Zevahiri, Tahkîkü't-tâm fì ilmi'l-kelâm (Kahire: Mektebetü'l-Hicazi, 1939), 13. 
ona ulaştırma süreci olarak tarif etmektedir. Nazar kişiyi ya bilgiye ya da zann-1 galibe ulaştırmaktadır. Şartları haiz olmayan ve fasid nazar olarak bilinen kısmı bilgi ifade etmezken sahih nazar kişiyi kesin bilgiye götürmektedir. Yine Cüveynî, nazarın bilgi, cehalet ve şüphenin zıddı olduğunu ifade etmektedir. İlim kesin, cehalet bir şeyi hakikatinden farklı bilme ve şüphe ise iki inanç arasında karar verememe durumu olduğu için bu durumda nazar olmaz. Bilgi, cehalet ve şüphede hakikati arama durumu söz konusu olmadığından nazar da gerçekleşmez. $\mathrm{Bu}$ nedenle bunlar nazara zıttır. ${ }^{30}$ Çünkü nazarda, bilgiye ulaşma süreci ve çabası söz konusudur ve bu nedenle henüz varılmış bir hüküm yoktur.

Fahreddin Râzî̀ye göre kesin ve zannî önermelerin tertibi olan nazar ile kişi kesin bilgi veya zannî bilgiye ulaşır. Nazar doğru ve kesin öncüllerden oluşursa bu durumda nazar ilim ya da doğru bir itikadı gerekli kılar. ${ }^{31}$ Râzî bilgiyi tasavvurî ve tasdikî olmak üzere ikiye ayırdıktan sonra, tasdikin ya bedihî/kesin veya nazarî olduğuna vurgu yapar ve bu konuda değişik tasniflere yer verir..$^{32}$ Aynı şekilde bilginin tasavvurî veya tasdiki olduğunu belirten Teftâzânî, his ve akılla idrak edilen bilginin yakīn/kesin olabileceği gibi olamayabileceğine de dikkat çekmektedir. Yine yaptığı bir diğer tarife göre bilgi sahibine nakzedilme ihtimali vermeyecek şekilde ayrıştırma sağlayan bir sıfattır. Bu son tanım yakīni olmayan bilgileri kapsam dışında bırakmaktadır..$^{33}$ Görüldüğü üzere kesin bilginin temininde önemli bir vurguya sahip olmalarına rağmen hangi bilgi kaynağı ve yöntemle bunun sağlanacağı hususunda bir ittifaktan söz edilemez.

İlim, inanç ve zan arasında kesinlik/cazım, uygunluk/mutabık ve değişmezlik/sabitlik yönünden farklı hükümler/haller bulunmaktadır. Bu farklı hallerden dolayı ilim, cehalet, taklit, zan, şek, vehim ve hayal gibi değişmezlik, kesinlik ve uygunluk yönünden farklı seviyelerde bilgi mertebeleri söz konusudur. ${ }^{34}$ Hükümde kesinlik, uygunluk ve değişmezlik varsa yakini bilgi (elilm) söz konusu olur. Buradaki bilgide nakzedilme/yanlışlanma ihtimalinin olmaması kaydı cehalet, vehim ve zan gibi yakīni olmayan hükümleri tarifin dışına çıkarmak içindir. ${ }^{35}$ Hükümde kesinlik söz konusu olmakla beraber -zayıf bir ihtimal de olsa- uygunluk ve değişmezlik durumunun olmama ihtimali halinde itikat gerçekleşmiş olmaktadır. Kesinlik, uygunluk ve değişmezlik değeri açısından bir netliğin oluşmaması durumunda ise zan tahakkuk etmektedir. ${ }^{36}$ İlim kesinlik ile zan, şüphe ve vehimden ayrılırken; uygunluk ile cehaletten ve malumun değişmesiyle de mukallidin imanından ayrılır. ${ }^{37}$ Ancak tasavvurî bilgilerde vakıaya mutabakat veya adem-i mutabakattan bahsedilemez. ${ }^{38}$ Çünkü tasavvurî bilgilerde hüküm yoktur.

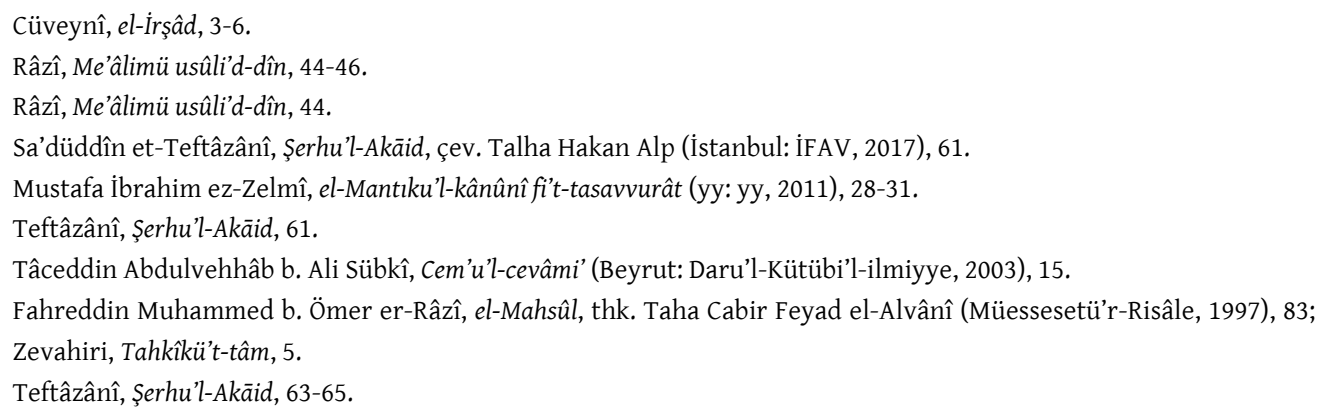


İdrak mertebeleri (merâtibü'l-idrâk) açısından zannîlikten kat'îliğe doğru bir sıralama yapıldığında cehalet-vehim-şek-zan-itikad/ilim şeklinde bir sıralama yapılabilir. Bir bilginin doğruluk değeri ve derecesi bilgi doğrusu üzerinde şöyle gösterilebilir:

Cehalet --> Vehim --> Şek --> Zan --> İtikat/Bilgi

Bu bilgi doğrusu varlığın bilgisi hakkında verilen hükümlerin doğruluk değeri ve kesinliği konusunda artan bir derecelendirmenin var olduğunu göstermektedir. Cehalet, bu idrak mertebelerinden hiç birisinin bulunmamasını ifade etmek için bilgi doğrusu üzerinde vehimden önceye konulmuştur. Cehalet, bilginin yokluğunu ifade ettiğinden bilgi değeri taşımamaktadır, ancak bilginin zıttı olarak bilgi doğrusu üzerinde gösterilmiştir. İlmin yokluğuna veya zıddına cehalet, doğruluk payı \%50'nin altında olanına vehim, \%50 olanına şek, \%51 ile \%99 arasına tekabül edenine de zan adı verilmektedir. Doğruluk değeri ilme yakın olana zann-1 galip/kuvvetli zan, şekke yakın olana ise zann-1 âdi/sıradan zan denilmektedir. Görüldüğü üzere zannın kapsam alanı kesin bilgiye doğru ilerleyen geniş bir bilgi derecelendirmesini ve kesinlik değerini ifade etmektedir. Şek ve vehmi de zan kategorisinde değerlendirenlerin olduğuna yukarıda işaret edilmişti. ${ }^{39}$

Şek veya vehim anlamında kullanılacak olan zannın bir değeri olmadığı gibi bağlayıcılı̆̆ı da söz konusu değildir. Çünkü şek ve vehimde iki ihtimalden birini diğerine tercih etmenin bir delili, emâresi veya gerekçesi yoktur. Ancak şek, kişiyi inançta küfre düşürürken hukukta bazı durumlarda masumiyet karinesi olarak suç isnadını düşürmektedir. Zanda ise durum farklıdır. Hukuki hükümlerin çoğu zanna dayandırılmakta ve amel noktasında bağlayıcı bir nitelik taşıyabilmektedir.

Gazzâlî (ö.505/1111), itikat ile bilgi arasındaki ilişkiyi değerlendirirken bilginin itikattan farklı olduğuna vurgu yapmaktadır. O, bunu şu şekilde ortaya koyar: "Itikat, şâkkın (şüphe içerisinde olanın) iki itikadından birisinin öne çıkması olup, kişi bu itikada, bunun zıddını aklnna getirmeksizin ve bu zıddın nefse girmesine imkân vermeksizin vakıf olmuştur." Kesinlik açısından bilgi ile kıyaslandığında itikadın da zannın bir türü olduğunu; ancak taşıdığı görecelik açısından ondan ayrıldığını belirtir. ${ }^{40}$

İtikadın aynılık, ayrılık, içlem ve kaplam açısından zan ve bilgiyle ilişkisi değerlendirildiğinde zan mi yoksa bilgi mi olduğu akla gelmektedir. Bu konuda Müslüman kelâmında önemli tartışmalar vardır. Mu'tezile ekolünün ve Teftâzânînin bilgiyi itikad üzerinden tanımlaması dikkati celbeden bir yaklaşımdır. İtikad ile bilgi arasında doğruluk, kesinlik ve uygunluk açısından çok yakın bir ilişki olduğunu göstermektedir. Aynı zamanda itikat ile bilgi arasında bir geçirgenlik ve esneklik söz konusudur. İlim inanç, inanç ilim olabilmektedir. Ancak ilmin itikat üzerinden tanımlanması Mâtürîdî ve Eş'arî gelenekte ciddi bir şekilde eleştirilmişse de ${ }^{41}$ i'tizalî

39 Bk. Râzî, Me'âlimü usûli'd-dîn, 44; el-Hın, el-Kat'̂̀ve'z-zannî, 79-83.

40 Gazzâlî, Mustasfa, 1/33. Gazzâlî, mu'tekid, şâk ve cahil kişinin durumuna şunu örnek verir. Şâk, "Âlem hadis midir yoksa değil midir? der. Mu'tekid kanaati belirlendiği için "Âlem hadistir” der ve kıdemin imkânına gönlünde yer vermeksizin bu inanç üzerine devam eder. Cahil ise "Âlem kadimdir" der ve bu inanç üzerine devam eder. Bk. Mustasfa, $1 / 33$.

41 Bk. Ebu'l-Muin Meymun b Muhammed en-Nesefi, Tebsıratü'l-edille fì usûli'd-dîn., thk. Hüseyin Atay (Ankara: Diyanet İşleri Başkanlığı, 2004), 1/9-30. 
düşüncede bu itikad, nazar ve delille gerekçelendirilmesi ile mu'tekidin/inananın duyusal ve zihinsel itminanı sağlaması durumunda bilgiye dönüşmektedir. Bu yaklaşım bugün çağdaş batı epistemolojisinde de "bilgi doğrulanmış inançtır" (the knowledge is justification belief) şeklinde kendisine yer bulmaktadır. ${ }^{42}$ Tüm bu değerlendirmeler ilmin mutlak olarak inançtan ve zandan bağımsız olarak ele alınamayacağını ve bu kavramlar arasında sıkı bir iliş̧kinin var olduğunu göstermektedir.

Verilen bu temel ve genel bilgilerden sonra İslam düşüncesinde zannî bilgi kategorisinde ne tür bilgilerin yer aldığına değinebiliriz. Bilgileri, zannîlikten kesinliğe/yakīniliğe doğru bir derecelendirmeye tabii tuttuğumuzda hangi aklî ya da naklî bilgilerin zan, hangilerinin yakīn (itikat/bilgi) ifade ettiği konusunda kelâmcılar görüş birliğine sahip değildirler. Konumuz açısından önemli olan zannî bilgilerin neler olduğu ve bu bilgilerin nasıl değerlendirildiğidir. İslam düşüncesinde zannî bilgi kategorisinde sayılan bilgiler iki ana başlık altında ele alınabilir. Bunlar; akla dayalı zannî bilgiler ve nakle dayalı zannî bilgilerdir.

\section{Aklî Bilgilerin Zannîliği ve Değeri}

Bilgi kaynaklarının ve istidlal yöntemlerinin sağladığı hükümlerin kesinliği ve zannîliği bağlamında farklı görüşler ileri sürülmüştür. Bilindiği üzere kelâmda bilgi kaynakları duyu, haber ve akılla sınırlandırılmıștır. İlham, rüya, vicdan, hads gibi bilgi kaynakları güvenilir, objektif ve kesin bilgi sağlamadıklarından bağlayıcı kabul edilmemiştir. ${ }^{43}$ Kelâmî epistemolojide selim akıl, sağlam duyu ve sadık haberin kesin bilgi sağladığı hususunda görüş birliği söz konusudur. Kelâmcılar; sofistler ve Sümeniyye'nin bu bilgi kaynaklarının objektif ve kesin bilgiler sağlamadığına yönelik eleştirilerine şiddetle karşı çıkmışlardır. Kelâmcılara göre onların bilgi kaynaklarını kullanırlarken objektif ve kesin bilgilere erişmemelerinin asıl nedeni, istidlal araçlarını doğru bir şekilde (sahih nazar) kullanamamalarıdır. ${ }^{44}$

Aklın epistemik değeri ve rolü konusunda Müslüman düşünürler arasında birçok farklı görüş mevcuttur. ${ }^{45}$ Filozoflar, mantıkçılar ve kelâmcılar nakilden bağımsız aklî temelde kesinlik ve zan ifade eden önerme ve bilgi türlerini ele alırlarken hangi bilgi ve yöntemlerin kesin bilgi sağladığına ilişkin bir görüş birliği içinde olmamışlardır. Bununla beraber genel olarak geçerli aklî/mantık ilkelerine dayanan istidlal yöntemlerinin (kıyas/tümdengelim, istikrâ-i tam/bütün tikellerden hareketle tümevarım) kesin bilgi sağladığı hususunda görüş birliğinde olmuşlardır. ${ }^{46}$ Öncülleri bedihiyyât ve yakīniyattan oluşan burhanî bilgi sübjektif/zannî değil, aksine objektif ve genel geçer bir bilgidir. Kelâmcilara göre doğru kurulmuş kesin önermelerden zorunlu olarak kesin bir bilgi ortaya çıkar. Böyle bir bilginin doğruluğundan şüphe edilmez; çünkü doğrudan

${ }_{42}$ V. W. Quin - J. S. Ullian, The Web of Belief (Newyork: McGraw-Hill Education, 1978). Bu kitabın Türkçeye "Bilgi Ağı" şeklinde tercüme edilmesi de -ki orijinali “İnanç Ağı”dır- dikkati celbeden bir durumdur. V. W. Quin - J. S. Ullian, Bilgi Ağı, çev. Hadi Adanalı (Ankara: Kitabiyat, 2001).

43 Kelamda bilgi kaynakları ve problemine ilişkin genel bilgi için bk. Harun Çağlayan, Kelam'da Bilgi Kaynakları (Ankara: Ankara Üniversitesi / Sosyal Bilimler Enstitüsü /, Doktora, 2009); Murat Memiş, Kâdı Abdülcebbâr'da Bilgi Problemi (İzmir: Dokuz Eylül Üniversitesi / Sosyal Bilimler Enstitüsü, Doktora, 2007).

${ }_{44}$ Teftâzânî, Şerhu'l-Akāid, 62.

45 Bk. Ramazan Altıntaş, “Kelami Epistemolojide Aklın Değeri”, Cumhuriyet Üniversitesi İlahiyat Fakültesi Dergisi 5/2 (15 Aralık 2001), 97-130.

46 Bu konularda detaylı bilgi için bk. el-Hın, el-Kat'î ve'z-zannî, 29-30; Zevahiri, Tahkîkü't-tâm, 15-21; Metin Özdemir, “Kelâmî İstidlâlin Problematiği”, Cumhuriyet Üniversitesi îlahiyat Fakültesi Dergisi 5/2 (2001), 180. 
başka bir ihtimali yoktur. Kelamcılar genel olarak şu bilgi türlerinin yakīni bilgi sağladığını dile getirmişlerdir: Bedihiyyât (apaçık ve kesin bilgiler), müşahedât (duyular vasıtasıyla elde edilen bilgiler), fitriyyât (zihinde mevcut olan bilgiler), mücerrebât (tecrübeye dayalı bilgiler), mütevâtirât (yalanlanması aklen mümkün olmayan haberler) ve hadsiyyât (akli sezgi) türü bilgileri bu kabilden saymışlardır. ${ }^{47}$ Bununla birlikte bu tür bilgilerin kesbi ya da zorunlu olduklarına dair tartışmalar yapılmıştır. ${ }^{48}$

Aklî istidlale dayandığı halde doğru olmama ihtimali bulunan önerme ve bilgi türleri de mevcuttur. Râzî, iki kesin önermenin neticesinin kesin, bir veya iki zannî önermenin neticesinin zannî olduğuna vurgu yapmaktadır. ${ }^{49}$ Zannî bilgiden zannî bilgiye erişim imkânı varken zannî bilgiden kesin bilgiye erişim imkânı yoktur. Yine bütün tikellerden hareketle varılan tümel bilgi şeklinde tanımlanan istikrâ-i tam ile yapılan aklî istidlal kesin bilgi, bir kısım tikellerden hareketle elde edilen tümel bilgi olan istikrâ-i nakıs ise zannî bilgi ifade eder. ${ }^{50}$ Zanniyyâttan olan bu tür bilgiler farklı ad ve tasniflere tabi tutulmuştur.

İslam felsefesinde ve müteahhirûn kelâmında genel olarak aklî kategoride zannî kabul edilen başlıca bilgi/önerme türleri şunlardır: Meşhûrât; halk arasında yaygın olarak kabul edilen bilgilerdir. Bu tür bilgiler/hükümler toplumun din, kültür, gelenek ve eğitim anlayışı gibi unsurların etkisiyle benimsenir ve yaygın bir kabul haline gelir. Meşhûrât kategorisindeki bilgilerin doğruluğundan şüphe edilmese bile aklın kesin olarak bildiği delillere dayanmadığından yakīniyattan sayılmaz. Bu bilgilerin veya hükümlerin yanlış olma ihtimali vardır. Meşhûrâta genelde "adaletin iyi”, “zulmün kötü” olduğu bilgisi örnek verilir. Müsellemât; muarızın benimsediği bir ilkeyi veya görüşü esas alarak kendi görüşünün doğruluğunu bina ettiği hüküm veya bilgidir. Her ilmi disiplinin kendine ait müsellemâtı vardır. Bu tür bilgiler daha ziyade cedeli kıyasta kullanılır. Makbûlât kategorisindeki bilgiler nebi ve veli örneklerinde olduğu gibi dinde ya da herhangi bir alanda otorite kabul edilen şahıslardan alınan bilgilerdir. Makbûlât, güvenilir kabul edilmekle birlikte kesinlik taşımaz ve yanlış olma ihtimali vardır. Maznûnât; başka ihtimallere açık olmakla beraber aklın tercih ettiği önermelerdir. Vehmiyyât; insanın vehim gücüyle doğru kabul ettiği bilgiler veya hükümlerdir. Muhayyelât kategorisindeki bilgiler ise insanın psikolojik durumuna bağlı olarak gelişen bilgilerdir. Bu bilgilerin objektifliği olmadığı gibi mantıki yönü de yoktur. Retorikte hayalin ürettikleri öncüller

47 Bk. Teftâzânî, el-Makāsıd, 102; Gazzâlî, Mustasfa, 1/59-61. Gazzâlî, bunları evveliyat, bâtınî müşahedeler, dış duyular, tecrübi şeyler ve mütevâtir bilgiler olarak nitelemektedir. Cürcanî ise zorunlu kesin önermelerin yedi tane olduğu ifade etmektedir: Evveliyat, kıyasları beraberinde olan önermeler, müşahadât, mücerrebât, hadsiyyât, mütevâtirât ve duyulardaki vehmiyyâttır. Cürcânî bunlar arasında bile bir derecelendirme yapmakta, evveli bilgileri en başa, sonra kıyasi önermeleri, müşahedât ve vehmileri almaktadır. Ayrıntılı bilgi için bk. Ebü'l-Fazl Adudüddin Abdurrahman b Ahmed b Abdülgaffar Îcî, Kitâbü'l-Mevakıf (Beyrut: Dârü'l-Cil, 1997), 1/196-198.

48 Ayrıntılı bilgi için bkz. Teftâzânî, Şerhu'l-Makāsıd, 1/70-75; Gazzâlî, Mustasfa, 1/59; Ali Mahmood Al-Omarî - Hakan Kutlu, "Müteahhirûn Kelâmında Kullanılan İstidlâl Metotları", Kocaeli i̇lahiyat Dergisi 3/2 (28 Aralık 2019), 125-144; Zevahiri, Tahkîkü't-tâm, 8-9.; Gazzâlî, Mustasfa, I/59; Ali Mahmoud al-Omerî ve Hakan Kutlu, "Müteahhirûn Kelamında Kullanılan istidlal Metotları”, Kocaeli İlahiyat Dergisi, 3/2, ss. 125-144; Muhammed Hüseyni, Tahkikü't-tam fi ilmi'l-kelam. 8-9.

49 Râzî, Me'âlimü usûli'd-dîn, 48.

50 Sübkî, Cem'u'l-cevâmi', 108. 
sıklıkla kullanılır. ${ }^{51}$ Gazzâlî vehmiyyat ve meşhûrâtın burhan kategorisinde olduğunun vehmedildiğini; ancak bunların gerçekte yakīn ifade etmediğini, zan ifade ettiğinden fikıh ve cedeli kıyasta kullanılabileceğini belirtmektedir. ${ }^{52}$

Yukarıda bahsedilen bilgi türleri İslam felsefesi ile müteahhirûn dönemi kelâmında aklî istidlalde ve diyalektikte kullanılmaktadır. Mantıkçılar da meşhûrât ve makbûlât türünden bilgileri cedeli kıyasta argüman olarak kullanmıșlar; ancak bu tür bilgiler onlara göre zan ifade ederler. Müteahhirûn dönemi kelamcılarının, filozofların tesirinde kalarak kullandıkları istidlal yöntemlerin sonucunda ulaşılan bilgilerde de farklı düzeylerde zannîlik söz konusudur. Kelamcılar, bahsedilen bilgi türlerinden hangilerinin kesinlik ve zannîlik sağladığı noktasında farklı görüşlerde olmuşlardır. ${ }^{53}$ Gazzâlî, meşhûrât ve kıyasın zan ifade ettiğini ve fikıhta fayda sağladığını dile getirmektedir..$^{54}$ Seyfeddin Âmidî zannî bilgi yelpazesini daha geniş tutmakta, tümdengelim (kıyas) dışındaki aklî istidlal çeşitleri olan istikra, temsil, in'ikas-1 edille, kıyasü’lgaib ale'ş-şahid gibi delillerin zan ifade ettiğini belirtmektedir. Âmidî, meşhûrât, müsellemât ve makbûlât gibi iknaî ve hatâbî delillerin itikadî konularda delil olarak kullanılamayacağını; ancak fikıhta kullanılabileceğini vurgulamaktadır. ${ }^{55}$ Cürcânî, sadece emârede kullanılan zannî önermelerin dört olduğunu ifade etmektedir. Bunlar; müsellemât, meşhûrât, makbûlât ve karinelerle varılan (makrûnetü bi'l-karaîn) hükümlerdir. ${ }^{56}$

Kelâmcılar Allah'ın varlığı, birliği, ilahi sıfatların zat ile ilişkisi, Allah'ın âlemle ilişkisi ve âlemin hadis oluşu gibi konularda naklî delillerden ziyade aklî istidlal süreçlerini işletmişlerdir. Yerine göre kıyas, istikra, sebr ve taksim ve istidlâl bi'ş-şâhid ale'l-gâîb gibi aklî istidlal yöntemleri ile bu konuları temellendirmişlerdir. Ancak burhan değil de hatâbe kabilinde sayılan yukarıdaki paragraftaki önermeler, kelâmcılar tarafından akîdenin ana konularının savunusunda veya cedeli tartışmalarda yardımcı argüman olarak kullandıkları söylenebilir. Müteahhirûn kelâmı epistemolojisi, felsefe ve mantığın istidlal biçimlerinden önemli oranda etkilendiği için bu kavramlar İslam kelâmının umur-u amme bahislerine dâhil edilmiştir. Ancak kelâmî meselelerin temellendirilmesinde bu tür argümanları çok sık kullandıklarını söylemek doğru değildir. Teftâzâni, mütekaddimûn dönemi kelamcılarından ziyade müteahhirûn dönemi kelâmcılarının İslam filozoflarından etkilenerek atıfta bulunduğu vicdaniyat, bedîhiyyât, hadsiyyât, tecrübiyât ve nazariyat türü bilgilerin akıl vasitasıyla gerçekleştiğini ifade etmektedir. ${ }^{57}$ Burhan seviyesinde olmayan bu tür önermeler, cedel ve münazaralarda muhatabını ilzâm ve/veya ifhâm etmenin (ikna edip susturma) yanında kendi görüşlerini haklı çıkarmak gayesiyle destekleyici argümanlar olarak kullanılmıştır. Her ne kadar bu tür önermeler zorunlu veya kesin bilgi ifade etmese de akıl, zannî bilgiyle amel etmenin gerekli olduğuna da hükmeder. Çünkü akıllı kişi, iki delilden doğruluğuna kanaat getirdiği delili (râcih) bırakıp zayıf olanla (mercûh) amel etmez.

51 Hüseyin Şahin, “Kelamcılara Göre Delil ve Delil Türleri”, KADER Kelam Araştırmaları Dergisi 13/1 (13 Şubat 2015), 465-466; Çağrıcı, “Zanniyat”, 44/124.

52 Ayrıntılı bilgi için bk. Ebû Hamid Muhammed b Muhammed Gazzâlî, el-Mustesfa min ilmi'l-usul, thk. Muhammed Yusuf Necm (Beyrut: Dâru Sadr, 2010), 1/55-60.

53 Bk. Özdemir, "Kelâmî İstidlâlin Problematiği”, 179-185.

54 Gazzâlî, Mustasfa, 1/64; Al-Omarî - Kutlu, "Müteahhirûn Kelâmında Kullanılan İstidlâl Metotları”, 132.

55 Vezir Harman, “Seyfeddin Amidî’nin Kelam Sisteminde Kat'ilik ve Zannilik Açısından Deliller”, KADER Kelam Araştırmaları Dergisi 10/2 (15 Temmuz 2012), 132.

56 Bk. Îcî, Kitâbü'l-Mevakıf, 1/199-200.

57 Teftâzânî, Şerhu'l-Akāid, 62-63. 
Dolayısıyla bu kabilden zannî bilgilere her zaman kişinin düşüncesini, duygularını ve eylemlerini yönlendirme ve belirleme gücüne sahip olduğu için muhatabını veya muarızını ilzâm etmek için başvurulmuştur.

Mutekaddimûn dönemi kelâmında Mu'tezile ve Eş’ari kelâmcılar tarafından özellikle ilahi zat ve sıfatların izahında müracaat edilen aklî bir istidlal yöntemi olan istidlâl bi'ş-şahid ale'l-gâî̉b, önce Cüveynî, sonrasında Gazzâlî ve Fahreddin Râzî gibi düşünürlerce kıyasın formu ve unsurlarını tam taşımadığından kesin bilgi sağlamadığı ve yanlış yargılara götürebileceği yönünde eleştiriler yapılmıştır. Yine mütekaddimûn kelâmcılarla kullanılan naklî delil ve in'ikâsı edille gibi deliller de Gazzâli ve Râzî gibi müteaahhirûn kelâmcılar tarafından kesinlik sağlamadığı yönünde tenkitlere konu olmuştur.

\section{Naklî Bilginin Zannîliği ve Değeri}

Naklî bilginin doğruluk değeri hususunda farklı ihtimaller söz konusu ise bu bilgi zannîdir. Kavramsal olarak "doğru ve yanlış olma ihtimali olan söz" diye tarif edilen haber, tanımı gereği yakīn ifade etmez. Bir haberin yakīn ifade etmesi için bazı şartlar aranmış ve doğru haberi tespit etme gayesiyle bazı hususlar gerekli görülmüştür. Temel bilgi kaynağı haber olan tarih ve hadis gibi disiplinler bu konuda daha fazla yöntem arayışına girmişlerdir. Doğru haberin tespiti gayesiyle eleştirel ve tenkitçi metodolojiler oluşturmuşlardır.

Kelâmcılar, naklin/haberin epistemik değerine büyük önem atfetmiş, haberin yakīn mi zan m1 ifade ettiği konusunda farklı değerlendirmelerde bulunmuşlardır. Kelâmcıların haberin epistemik değeri üzerinde önemle durmalarının asıl nedeni dini inancın dayandırıldığı nas olan ayet ve hadislerin haber yoluyla aktarılmasıdır. Hz. Muhammed'in peygamberliğinin ispatını sağlayan mucize haber yoluyla aktarılmıştır. Dolayısıyla haberin epistemik değeri konusunda kelâmclların "haber zorunlu bir şekilde bizde oluşur ve kesinlik ifade eder" görüşü önem arz etmektedir. ${ }^{58}$ Haberin kesin bilgi ifade ettiğini temellendirmek için sadece dini bilginin haberle elde edildiğini değil, aynı zamanda tarihi bilgilerin, uzak beldelerin, geçmiş milletlerin ve şehirlerin bilgisinin de haberle elde edildiğini ileri sürerek epistemik değerini ortaya koymuşlardır. Ancak yine de kelâmcılar, haberî bilginin zannî olduğu yönünde değerlendirmeler yapmışlardır. Bu tür değerlendirmelerin daha ziyade felsefe ve mantıktan etkilenen müteahhirûn kelâm döneminde yapıldığı görülmektedir. Ancak haberin zandan çıkıp yakin ifade etmesinin imkân ve yollarını ortaya koymuşlardır. ${ }^{59}$ Bunun hem aklî temelini hem de pratik yönlerini göstermişlerdir. Peygamberin haberiyle sabit olan bilginin vakıaya uygun, kesin ve değişmez bir nitelikte olması gerekir. Aksi takdirde bu niteliklerin sırasıyla zıddı olan cehalet, zan ve taklit olması icap eder. ${ }^{60}$ Bunlar da kesin bilginin zıt ve çelişiklerini oluşturmaktadır.

Kelâmcılar haberi; doğruluk ve yanlışlık ile kesinlik ve zannîlik yönleri itibariyle taksim etmişlerdir. ${ }^{61}$ Bilindiği üzere kelâmcılar genel olarak mütevâtir haberin kesin, âhâd haberin ise zan ifade ettiğini kabul etmektedirler. Kelâmcılar arasında mütevâtir haberin bilgi ve delil değeri

58 Cemalettin Erdemci, “Kelam İlminde Haberin Epistemolojik Değeri”, Dinbilimleri Akademik Araştırma Dergisi 6/4 (01 Ağustos 2006), 154.

59 Bk. Râzî, Kelam'a Giriş, 38.

60 Teftâzânî, Şerhu'l-Akāid, 83.

61 Bk. Erdemci, “Kelam İlminde Haberin Epistemolojik Değeri”, 161. 
konusunda bir görüş birliğinden söz edilebilir. ${ }^{62}$ Fakat mütevâtir haber sonucunda oluşan bilginin zorunlu mu yoksa kesbi mi olduğunu tartışmışlardır. Ebu Ali el-Cübbâî (ö. 303/916), Ebu Hâş̧im el-Cübbâî (ö. 321/933) ve Kādî Abdülcebbâr (ö. 415/1025) mütevâtir haberin zorunlu, Ebü'l-Kāsım el-Belhî (ö. 319/931) ise kesbi olduğunu ifade etmiştir. Ebü'l-Hüseyin el-Basri'ye (ö. 436/1044) göre mütevâtir haberle elde edilen bilginin durumu istidlalle elde edilen bilgi gibi olduğundan o da kesbidir. ${ }^{63}$ Ebü'l-Hüseyin ve Cüveynî, mütevâtir haberin nazari bilgi ifade ettiğini söylemişlerse de diğer kelâmcllara göre mütevâtir haber zorunlu olarak oluşur ve kesin bilgi ifade eder. Her ne kadar mütevâtir haberdeki her bir râvinin rivayeti zan ifade etse de yalan söylemeleri üzerinde ittifak etmeleri aklen ihtimal dışı olan farklı kişilerin rivayetinden oluşan bu haber kesinlik oluşturur. ${ }^{64}$

Fahreddin Râzî başta olmak üzere kelâmcılar genel olarak naklî delilin zannî aklî delilin ise kesinlik ifade ettiğini belirtmiştir. ${ }^{65}$ Râzîye göre naklî delil aklî delile kıyasla fer konumundadır ve zan ifade eder. Çünkü nakilden oluşan bir haber; müşterek, mecaz, takdir, anlam kayması, tahsis, takdim-tehir, nesh gibi dildeki bu anlam ihtimallerini taşıdı̆̆ı için yakīni bilgi ifade etmez.. ${ }^{66}$ Râzîye göre naklî delilin yakīn ifade edebilmesi ancak naklin delâletinin kesinliği ile mümkündür. Bu da naklin yukarıda zikredilen dilsel niteliklerin hiç birisini barındırmaması durumunda mümkün olabilir. ${ }^{67}$ Bu yaklaşım, naklî delil olan Kur'an'ı da kapsadığından problemli bir durum arz etmektedir. Zannîlik ifade eden âhâd haberin kelâmcılar tarafından delil olarak kullanılması ilkesel olarak kabul görmemişse de özellikle sem'iyyât bahislerinde sık sık kullanıldığı ve bu tür haberlerle istidlalde bulunduğu bir gerçektir. Başta Mâtürîdî (ö. 333/944) olmak üzere kelâmcılar haber-i vâhidin bilgi değerinin varlı̆̆ını kabul ederler. ${ }^{68}$

Râzîye atfedilen cümlelerde onun neyi kastettiği tartışılmış, onun bu ifadeleri tevil edilmiş ve bazı âlimlerce eleștiri konusu yapılmıştır. Zerkeşî (ö. 794/1392), Râzînin naklî bilginin dilin farklı anlam ihtimallerinden dolayı kesinlik ifade etmediği görüşünün doğru olmadığına dikkat çekmekte ve Îcînnin (ö. 756/1355) bunu güçlü bir şekilde reddettiğini vurgulamaktadır. Bir dilde kullanılan kavramların kesinlik ifade etmediğini söylemek toplumsal iletişimin ve uylaşımın/muvazaanın mümkün olmadığını söylemekle aynı anlama gelmektir. Nitekim Hz. Peygamber zamanından günümüze değin dilciler tarafından birçok kavram aynı anlamları ihtiva ederek kullanılmıştır. Îcî ve Teftâzânî, naklî delillerin bazen kendisinden nakil yapılan şeyde gözlemlendiğini veya tevatür yoluyla nakledilmiş haberlerin yakin ifade ettiğini vurgulamaktadır. Bu tür karineler farklı anlam ihtimallerini ortadan kaldırmaktadır. ${ }^{69}$

62 Bk. Mustafa Selim Y1lmaz, "Kelâm İlminde Mütevâtir Haberin Bilgi ve Delil Değeri”, Dinbilimleri Akademik Araştırma Dergisi 18/1 (2018), 199-223.

63 Teftâzânî, Şerhu'l-Akāid, 75; Erdemci, “Kelam İlminde Haberin Epistemolojik Değeri”, 163.

${ }^{64}$ Bk. Teftâzânî, Şerhu'l-Akāid, 72-75; Erdemci, “Kelam İlminde Haberin Epistemolojik Değeri”, 162-164.

65 Râzî, Me'âlimü usûli'd-dîn, 50.

${ }_{66}$ Bk. Râzî, Me'âlimü usûli'd-dîn, 50; Râzî, Kelam'a Giriş, 38; Erdemci, "Kelam İlminde Haberin Epistemolojik Değeri”, 173.

67 Bk. Zerkeşî, Luktatü'l-'aclân, 36-37.

68 Bk. Nuri Tuğlu, “İmâm Mâturîdî'de Haber-i Vahidlerin Değeri”, Uluğ Bir Çınar: İmâm Mâturî̀î: Uluslararası Sempozyum Tebliğler Kitabı (Eskişehir, 2014), 583-588.

69 Îcî, Kitâbü'l-Mevakıf, 1/209; Zerkeşî, Luktatü'l-‘aclân, 37-38. 
Âmidî, naklî delilin kesin bilgi ifade edip etmediği konusunda iki tutumun var olduğuna dikkat çeker. Bu iki tutumdan biri naklî delilin yegâne kesin ve mutlak delil olduğunu savunan Haşevî görüş; diğeri ise haberin zan ifade edişinden hareketle naklî delilin zan ifade ettiğini savunan görüştür. Ancak Âmidî, bu iki yaklaşıma karşı temkinli bir tutum takınmaktadır. ${ }^{70} \mathrm{O}$, sem 'iyyât konularında naklî delillerin esas alınması gerektiğini, çünkü aklın tek başına anlayamayacağı konuların var olduğunu belirtmektedir. Dinin ilkeleri, ibadet şekilleri, vakitleri, insanın iki dünya saadetine taalluk eden şeylerin bilgisi ancak resulün haberi ve hadisi ile mümkün olabilmektedir. ${ }^{11}$

Âhâd haberin kesin bilgi ifade edip-etmediği veya itikatta bağlayıcı delil olup olamayacağı konusunda tartışmalar olmakla beraber Mutezile ve Ehl-i sünnet kelâmcılarının çoğu, tercihlerini kesin bilgi ifade etmediği yönünde ortaya koymuşlardır. Ancak başta selef, ehl-i hadis ve zahiri âlimler ise âhâd haberin delil olarak kullanılması gerektiğini savunmuşlardır. ${ }^{72}$ Kelâmcıların aklî meseleler arasında yer verdikleri Allah'ın varlığı, birliği ve sıfatları gibi itikadî hususlara selef âlimleri naklin kapsamında yer vermişlerdir. Onlar, birçok ayetin haber-i vahid ile ameli vacip kıldığını ve itikad ile ibadetin haber-i vahid ile sabit olma noktasında herhangi bir farkın söz konusu olmadığını ifade etmektedirler. ${ }^{73}$

Cüveynî, tevatür derecesine ulaşmamış bir habere aklî bir delilin eşlik etmesi veya bir mucize ya da mucize sahibinin sözü ile desteklenmesi durumunda bilgi ifade edeceğini aksi durumda tek başına kesin bilgi ifade etmeyeceğini söylemektedir. ${ }^{74} \mathrm{O}$, kesinlik isteyen konularda âhâd haberin kullanımının doğru olmadığına, çünkü haberin Hz. Peygambere nispetinin kesin olarak tespit edilemeyeceğine ve bu durumda haberin, sübût açısından kesinlik taşımadığına vurgu yapmıştır. Teftâzânî de âhâd haberin kesin bilgi ifade etmemesini Peygamberin haberi olması itibariyle değil, aktarılan haberin peygambere aidiyeti konusunda oluşan şüpheden kaynaklandığını aktarmaktadır. ${ }^{75}$ Teftâzânî, adil kişilerin rivayet ettiği âhâd haberler ile müçtehidi taklit etmenin, zan ve değişebilen bir itikad olduğunu söylemektedir. ${ }^{76}$ Teftâzânînin şserhu'lmakâsıd'daki "akîde konularında zanniyyâta itibar edilmez" cümlesi şöyle tevil edilmiştir: Bu durum, kesin itikadî hükümler ve kesin hüküm gerektiren durumlar için doğrudur. Ancak bununla "zannî bilgilere ulaşılmaz" kast edilirse bu geçersiz bir görüş olur. ${ }^{77}$ Teftâzânî ve diğer

Harman, “Seyfeddin Amidî’nin Kelam Sisteminde Kat'ilik ve Zannilik Açısından Deliller”, 140.

Harman, "Seyfeddin Amidînnin Kelam Sisteminde Kat'ilik ve Zannilik Açısından Deliller”, 131.

Haberi vahidin belli kriterlere uyması durumunda (râvinin adalet ve zabtı gibi) kesin bilgi ifade ettiğini savunan İbn Hazm, İmam Malik, İmam Şafi, Ahmed b. Hanbel, Muhasibi, Davud ez-Zahiri, İbn Hacer el-Askalani, Hişam b. Amr el-Fuvati, İbrahim en-Nazzam ve İbn Teymiyye gibi farklı itikadî anlayışları temsil eden âlimler olduğu gibi, âhâd haberin kesin bilgi ifade etmediğini, zan veya zannı galib ifade ettiğini savunan âlimler de olmuşlardır. Bu son görüş, Ehl-i sünnetin çoğu, Mu'tezile ve Haricilerin tamamını kapsayan Cumhurun görüşüdür. Ayrıntılı bilgi için bkz. Rıza Korkmazgöz, "Kelam İlminde Haber-i Vâhidin Bilgi ve Delil Değeri”, Dinbilimleri Akademik Araştırma Dergisi 18/1 (31 May1s 2018), 225-258.

73 Bk. Ahmed Adil el-Garib, Tesbîtu hücciyyeti haberi'l-vâhid. (yy: Merkezu Tefekkür li'l-Buhus ve'd-Dirasat, 2016), 178.

74 Bk. Erdemci, "Kelam İlminde Haberin Epistemolojik Değeri”, 165.

75 Teftâzânî, Şerhu'l-Akäid, 83.

76 Teftâzânî, Șerhu'l-Akāid, 96.

77 Muhammed Salih b Ahmed Garsî, Menhecü'l-Eş'aireti fi'l-akïde beyne'l-hakäik ve'l-evhâm. (İstanbul: Ravza Yayınları, 2006), 91. 
kelâmcıların zanniyyâta itibar etmedikleri konular temel inanç konularıdır. Özellikle Allah'ın varlığı, birliği, sıfatları, nübüvvetin imkânı ve gerekliliği gibi aklî istidlal gerektiren konulardır.

Erken dönem Mu'tezilî kelâmcılar -ỉbrahim en-Nazzâm (ö. 231/845), Ebü'l-Hüzeyl el-Allâf (ö. 235/849), Ebu Ali el-Cübbâî gibi- âhâd haberlerin itikatta delil olarak kullanılmasına pek yer vermemişlerdir. Ancak bu durum geç dönem Mutezilî bilginler için geçerli değildir. Söz gelimi Kādî Abdülcebbâr kabir azabının varllğının hak olduğunu ve buna inanma delilleri olarak delâlet açısından kesin olmayan bazı ayetlerin yanında bazı hadisleri sunmaktadır. ${ }^{78}$ Bununla birlikte o da diğer kelâmcılar gibi ilkesel olarak itikadî meselelerde âhâd haberlerin kullanımına rezerv koymaktadır. Kādî Abdülcebbâr, haberi kesin olarak doğru, kesin olarak yalan ile doğru ve yalan oluşu kesin olarak bilinmeyen haber şeklinde üçe ayırmakta ve bunları örneklerle izah etmektedir. 0 âhâd haberi doğru ve yalan oluşunun kesin olarak bilinmeyen haber kategorisinde ele almaktadır. Ona göre haber gerekli şartları taşıyorsa ibadet ve amelî konularda itibara alınır ancak itikadî meselelerde itibara alınmaz. ${ }^{79}$

Kelâm ilminde naklî/haberi bilgiler sübût ve delâlet açısından değerlendirmeye konu olmuştur. Kelâmcılara göre haberi bilginin itikadî açıdan bağlayıcı olmasının temel koşulu "hem sübût hem de delâlet açısından kat'î olması" gerektiğidir. Sübût açısından haberi bilgiler arasında bir derecelendirme yapılabildiği gibi delâlet açısından da bir derecelendirme yapilabilir. Sübûtta kat ̂̂lik bilginin varlı̆̆ına ilişkin bir kesinliğe götürürken delâlette kat'îlik, anlam yönünden bir kesinliğe götürmektedir. ${ }^{80}$ Sübût ve delâlet açısından kat'î olan haberi bilgi bağlayıcı olmaktadır. Sübût açısından kesinlik olmadığı takdirde bilginin kaynă̆ı, delâlet açısından kesinlik olmadığı zaman bilginin kendisinde/anlamında bir kesinlik oluşmaz. Aksine zannîlik oluşur. Kesin bilgi ile zannî bilgi arasında delile dayanma açısından ortaklık söz konusudur. Her ikisinde de delil olmalıdır. ${ }^{81}$ Ancak yakīni bilgide delil hem sübût hem de delâlet açısından kesinlik ifade ederken zannî bilgide ya sübût ya delâlet ya da her ikisi açısından kesinlik ifade etmemektedir. Yakīni bilgide farklı ihtimaller söz konusu değildir, hüküm sabit, vakıaya mutabık ve kesindir; ama zannî bilgide bütün bu yönler açısından farklı ihtimaller ve değerlendirmeler söz konusu olabilmektedir. Yakīni bilgide farklı mertebeler yoktur, hüküm sabit ve değişmezdir. Oysa zannî bilgide derecelendirme ve tercih söz konusu olabilmektedir. Yakini bilgide bir çatışma ve çelişki olmazken zannî bilgide bu mümkündür. ${ }^{82}$

Kelâmi literatürde bazı usûli meselelerin yanında birçok tâli inanç, sübût ve delâlet açısından zannî olan bilgi (rivayet, hüküm) ile oluşmaktadır. Haberi bilgi bazen sübût açısından kesinlik, delâlet açısından ise zannîlik ifade ederken bazen de delâlet açısından kesinlik sübût açısından zannîlik ifade edebilmektedir. Bu konuda bir kesinlik iddiasında olmak oldukça zordur. Nitekim

78 Kādî Abdülcebbâr, Şerhu'l-Usûli'l-hamse, 730-731.

79 Bk. Kādî Abdülcebbâr, Şerhu'l-Usûli'l-hamse, 768; Erdemci, “Kelam İlminde Haberin Epistemolojik Değeri”, 166.

80 Sahip Beroje, “Zannî Bilginin Mahiyeti, Dindeki Yeri ve Önemi”, Şarkiyat 9/2 (30 Kasım 2017), 955.

81 Yukarıda da ifade edildiği gibi bazı âlimler zannî bilgi için delil değil emâre kavramının kullanmanın daha uygun olduğunu ifade etmişlerse de burada ki delil emâreyi de içerecek şekilde kullanılmıştır.

82 Beroje, "Zannî Bilginin Mahiyeti, Dindeki Yeri ve Önemi”, 955-956. Yakīnî bilginin doğruluğu yönünde bir derecelendirme olmamakla beraber, bilginin kaynağı ve ayrıntılı bir şekilde idraki açısından bir derecelendirmeden bahsedilebilir. İlme'l-yakīn, ayne'l-yakīn ve hakke'l-yakīn ayrımını idrakin keyfiyetine ilişkin bir derecelendirme olarak okumak gerekir. 
kelâmî ekollerin inanç konulardaki farklı görüşleri, bu konulardaki bilgilerin sübût veya delâlet açısından kesinliği ve bağlayıcıllı̆ı hususundaki farklılığa dayanmaktadır.

İtikadî konularda haber sübût ve delâlet açısından kat î ise bu durumda bilgi kesin olup bağlayıcıdır, inkârı küfür kabul edilmiştir. Sübût açısından kat ${ }^{\wedge} i$ olup delâlet açısından kat'î olmayan bilgi de bağlayıcı olmakla birlikte inkârı küfür değildir. Çünkü delâlet açısından zan taşımaktadır. Sübût ve delâlet açısından zannîlik söz konusu ise itikatta belirleyici olmadığı gibi inkârı da küfür değildir.

Kelâmda haber kabul edilen Kur'an ve hadislerin kesinlik ve zannîlik ifade etmesi onların sübût ve delâlet açısından kat'î ve zannî oluşlarına bağlıdır. Kur'an-ı Kerîm ve mütevâtir haber sübût açısından kat'î, delâlet açısından hem kat'î hem de zannî olabilir. Âhâd haber ise sübût yönünden zannî ama delâlet yönünden hem kat'î hem de zannî olabilir.

Kelâmcılar, haberi bilgininin zannîliğinin kat îliğine oranla daha baskın oluşundan olmalı ki, görüşlerini daha ziyade aklî istidlal yöntemlerine başvurmuşlardır. Bununla beraber kelâmcılar, mütevâtir kabilinden olan haberlerin yakīn ifade ettiğini savunmuşlardır. Aynı şekilde istidlal aracıllı̆̆ıla mucize ile desteklenmiş kişinin verdiği haberin de kesinlik ifade ettiğini söylemişlerdir. ${ }^{83}$ Bu durumu şöyle açılkayabiliriz. Mucize ile desteklenen kişi, dürüst ve güvenilir bir kişi ise akıl, dürüst ve güvenilir kişiye itimat etmenin gerekliliğini kabul eder. Dolayısıyla mucize ile desteklenen peygamberin verdiği haberi doğru kabul etmek, itikadî bir gereklilik olsa da aklî bir zorunluluktur. Çünkü akıl, haberin doğru veya yanlış olmasının mümkün olduğunu ancak güvenilir kişilerle/araçlarla aktarılan bilginin doğru oluşunun zorunlu olduğunu ilkesel olarak kabul eder. Burada asıl olan, yanlış olma ihtimalini ortadan kaldırmaktır. Kelâmcılar bunu mütevâtir haber ve haber-i resul ile sağlamaya çalışmışlardır.

Netice olarak kelâmcılar ilkesel olarak haberi, zannî bilgi düzleminde ele almışlarsa da haberin kesinlik değerini kabul ederler. Haberin kesinlik ifade etmesini bazı şartlara bağlamışlardır. Bir haberin zorunlu veya kesin bilgi ifade etmesini ve kendisiyle istidlalde bulunulmasını; ancak tevatür derecesine ulaşması veya mucize ile desteklenmiş resulün haberi olması durumunda mümkün görmüşlerdir. Bununla beraber bazı kelâmcılar aklî istidlal imkânının zayıf olduğu kabir hayatı, mesih/mehdi anlayışı, ahiret ahvali gibi birçok itikadî hususun gerekçelendirilmesinde haber-i vahidi delil olarak kullanmışlardır.

\section{4. İtikadın Temel Çerçevesi ve Zannın Delil Olarak Kullanıldığı Alanlar}

İtikad; kesin delillere dayandırılması gereken ve dinin temel konularını ilgilendiren bir alan olduğundan kelâmcılar itikadî konuları yakīni bilgi sağladıklarını düşündükleri aklî istidlal yöntemleri ve naklî delillerle tespit etmiş ve ispat etmeye çalışmışlardır. Teftâzanî kelâmın gayesini inancı sağlamlıkla süsleme ${ }^{84}$, Cürcânî kişiyi taklit çukurundan yakīn zirvesine yükseltme şeklinde ortaya koyarken ${ }^{85}$ İbn Haldun (ö. 808/1406) kelâmın konularını inanç konularını aklî

83 Teftâzânî, Şerhu'l-Akāid, 78; Kādî Abdülcebbâr, Şerhu'l-Usûli'l-hamse, 768.

84 Teftâzânî, el-Makāsıd, 92.

85 Îĉ̂, Kitâbü'l-Mevakıf, 1/40; Seyyid Şerîf Cürcânî, Şerhu'l-Mevâkıf (İstanbul: Türkiye Yazma Eserler Kurumu Başkanlığı, 2015), 1/147. 
delillerle bid'atı ortadan kaldırma, şek ve şüpheyi izale etme şeklinde ortaya koymaktadır. ${ }^{86}$ Kelâmcıların tüm izahlarında şüpheden uzaklaştırılmış yakīn ifade eden bir inanç arayışı mevcuttur. Bu nedenle kelâmcıların bilgi kaynaklarını sağlam duyu organları (havas-1 selime), selim akıl (akl-1 selim) ve sadık haber (haber-i sadık) ile sınırlandırması, ${ }^{87}$ sahih bir akîdenin ancak kesin, doğru ve sabit olmasını mümkün kılacak epistemik kaynaklarla sağlanabilmesindendir. Kelâmcılara göre dinî inancın temel konuları ve çerçevesi ancak bu bilgi araçlarıyla mümkündür. Akıl ve duyu inancın aklî bir temelde anlaşllı gerekçelendirilmesinde kullanılırken nakil hem inancın gerekçelendirilmesinde hem de belirlenip temel çerçevesinin oluşturulmasında kullanılmaktadır. Akıl dinin anlamlandırılmasında önemli bir işleve sahip iken nakil dinin temel çerçevesini oluşturmada belirleyici olmaktadır. Bir dinin temel itikadî meselelerini belirleyen o dinin mensuplarınca kutsal kabul edilen metinlerdir. Bir başka ifadeyle deliller arasında naklin ağırlıklı olması, o dinin usul, esas ve gerekliliklerinin o dinin temel metinlerine dayandırılmasındandır.

Kelâmcılar, dinî akîdeyi oluşturan bazı konuları salt aklî delille, bazılarını salt naklî delille, bazılarını da hem aklî hem de naklî delille temellendirme ihtiyacı duymuşlardır. Mecâlü'l-'akl başlı̆̆ı altında Allah'ın varlığı, birliği, sıfat ve filleri, nübüvvetin imkânı ve gerekliliği gibi hususlar aklî istidlâl ile temellendirirlerken, mecâlü’n-nakl başlığı altında gaybî konular, ahiret ahvali gibi sem'i konular nakille ortaya konulmuştur. Rü'yetullah, hüsün ve kubuh gibi konularda da akıl ve nakil birlikte kullanılmıştır. ${ }^{88}$ Kelâm ilminde itikadî konuları sırf aklî ve/veya naklî delile indirgemek şeklinde bir tutum takınılmamıştır.

Kelâmcıların ilkesel olarak kabul ettikleri, "sübût ve delâlet açısından kat'î delille inanç temellendirilir” argümanının bazı itikadî konularda kullanma imkânının olmadığı görülmektedir. Zannî bilginin kelâm ilminin asıl meseleleri kullanılamayacağına ilişkin güçlü bir vurgu varken usûle/asla bağlı olan tâli meselelerde veya aslın temellendirilmesinde araç olarak kullanılan meselelerde (mebâdî, vesâil) kullanıldığı müşahede edilmektedir. Yine itikad cinsinden olan birçok konu sübût açısından kesin olmayan âhâd haberlere ya da delâlet açısından kesinlik ifade etmeyen bazı ayetlere dayandırılmıștır. Özellikle semiyyât bahisleri buna örnek verilebilir. Nitekim itikatta zannî bilgiye ve delile yer verilmemesi durumunda birçok konu kapalı kalabilmektedir. Dirilişe inanmanın gerekliliği sübût ve delâleti kat'î delille açıklanırken, kabir ve ahiret ahvaline ilişkin birçok inanç zannî delil kabul edilen rivayetler vasıtasıyla inanılmakta ve gerekçelendirilmektedir. Çünkü bu konular müşahede alanının dışında kalan gaybî konulardır. İtikadın ana ilkeleri, aklın ve duyuların idrak ettiği, keyfiyetini bildiği ve sınırlarını çizdiği bir çerçevede ele alınamazlar. Bu nedenle inançta temel belirleyen dini naslar olmaktadır. Söz gelimi ahiret, cennet, cehennem, melek gibi inanç konuları aklen caiz görülmekle beraber mantıksal çıkarımlara, duyuma ve deneyime konu olmadıkları için bu

86 Abdurrahman b. Muhammed i̇bn Haldun, Mukaddimetü İbn Haldun, thk. Seyyid Mahmud Ukeyyil (Beyrut: Daru'l-Cîl, 2013), 398.

87 Birçok kelamcı tarafından bu bilgi kaynaklarının (akıl, duyu ve haber) başına sırasıyla selim, sağlam ve sadık sıfatlarının getirilmiş olması, idrak yollarının keyfiyetine dönük bir hassasiyetin ifadesidir. Bu sıfatlar, bu kaynaklarla elde edilen bilgilerin sıhhatine ilişkin bir değerlendirme ölçütü verdiği gibi bu nitelikte olmayan bir kaynağın epistemik değerinin zayıf olabileceğini de göstermektedir.

88 Kādî Abdülcebbâr, Șerhu'l-Usûli'l-hamse, 194-195; Bâkıllânî, et-Takrîb, 1/228-231. 
konuda dinin hem sübût hem de delâlet açısından kesinlik ifade eden kurucu metinleri ile yetinmek gerekir.

İnanç konusu geniş bir yelpazede ele alındığından hangi inanç konularının kesin veya hangi konuların zannî bilgi ile tespit edilip temellendirileceği tartışılmıştır. Hangi inanç konularının kesin ya da zannî deliller üzerine bina edileceği hususunda genelde şöyle bir tasnif yapmak kabul görmüştür: Allah'ın varlığı, birliği ve zati sıfatları gibi bilinmemesi küfrü gerektiren konular ile Allah'ın kadim ve âlemin hadis oluşu gibi bilinmemesi günahı, inkârı da küfrü gerektiren konuların sübût açısından kesin delille temellendirilmesi gerekmektedir. Bu konularda zannî delil yeterli değildir. Şayet bu konular, sübût ve delâlet açısından kat'î delille temellendirilirse bu durumda âhâd habere ihtiyaç da kalmaz. Bunun dışında kalan bazı konularda zannî delil esas alınabilir. Bu konular Kur'an ve sünnete dayanmakla beraber sübût veya delâlet açısından zannî delil kapsamında olduğundan farklı anlamlara gelebilmekte ve tevile imkân tanımaktadır. Bu nedenle bu tür konuların inkârı bid'at veya günah olarak telakki edilmekle beraber küfür gerektirmemektedir. ${ }^{89}$

Kelâmcıların teorik düzeyde kabul ettikleri "itikadın kat'î delille temellendirilmesi"nin gerekliliği hususu pratikte sürdürülmesi ve savunulması zor bir husustur. Çünkü itikad nakle dayanmakta ve naklin ise kesinlik mi yoksa zannîlik mi ifade ettiği yukarıda ifade edildiği üzere tartışmaya açık bir konu olmaktadır. Tartışma konusu yapılan bir meselede aklî açıdan bir kesinlikten söz edilemez. İtikadın temel çerçevesinin yanında detaylarından söz edebilmek için zan kategorisinde olan bilgilerin kullanımı gerekli olmaktadır.

Kelâmcıların kullandıkları aklî ve naklî bilgilerin değeri, kat'îliği ve hüccetine yönelik bazı çevrelerden gelen eleştiriler kelâmcıların epistemolojisinde ve istidlal biçimlerinde bazı kırılmalara yol açmışır. Ehl-i hadis, filozoflar ve tasavvufçular kelâmcıların epistemoloji anlayışlarına önemli eleştiriler yöneltmişlerdir. Bunu fazla detaylandırmadan şöyle ifade etmek mümkündür: Selef ve hadis âlimlerinin, kelâmcıların hadislere yönelik tutumlarına tenkitleriyle birlikte süreç içerisinde, kelâmcıların itikadın tesisinde ilkesel olarak kabul ettikleri "sübût ve delâlet açısından kat'̂̂lik" ilkesinin esnediği söylenebilir. Ehl-i hadis ve selef ulemasının kelâmcıların âhâd haberin zannî olduğundan bağlayıcı delil kabul etmemelerine yönelik yaklaşımlarına sert eleştirileri olmuştur. Onlara göre dinin ibadet, muamelat kısmında olduğu gibi inanç kısmında da birçok konu ancak âhâd haberle temellendirilebilir. Naklî delille/âhâd haberle istidlalde bulunmak amelî alanda olduğu gibi itikadî bazı hususlarda da bir gereklilik olarak ortaya çıkmıştır.

İslam filozoflarının, kelâmcıların epistemoloji anlayışlarına ve istidlal yöntemlerine yönelik eleştirileri, kelâmcıların kullanmış olduğu yöntemlerin kesinlik sağlamadığı ve doğru sonuçlara ulaştırmadığı noktasında yoğunlaşmaktadır. Müteahhirûn dönemi epistemolojisinde bazı kırılmaların yaşanmasında felsefi ve tasavvufî düşüncenin kelâmî epistemolojiye yönelttiği eleștirilerin önemli bir etkisi söz konusudur. Naklî bilgilerin değeri, kat'̂̂liği ve hüccetinin güçlü oluşuna yönelik felsefi çevrelerden gelen eleştiriler kelâmcıların epistemolojisinde bazı esnemelere yol açmıştır. İslam filozoflarının, kelâmcıların istidlal yöntemlerine yönelik sert eleştirileri, kelâmcıların kullanmış olduğu yöntemlerin kesin ve doğru sonuçlara ulaştırmadığı

89 Garsî, Menhecü'l-Eş'aire, 89-90. 
noktasında düğümlenmektedir. Şöyle ki: Filozoflar Gâib'in şâhide delil getirilmesinin ulûhiyet meselelerin temellendirilmesinde doğru ve geçerli neticeler temin etmediği ve cedeli yöntemin burhandan ziyade hatâbî ${ }^{90}$ ve iknâî bir delil olarak kullanıldığını öngörmüşlerdir. Ancak filozofların bilgi kaynağı olarak aklı kullandıklarını söylemelerine rağmen ulûhiyet ve nübüvvet ile varlık ve bilgi gibi konulardaki bazı görüşleri, aklî temelde izahı oldukça zor ve delillendirilmesi akıldan ziyade bazı kabullere dayanmaktadır.

Yukarıdaki duruma sudûr nazariyesi, on akıl meselesi, vahiy ile faal akıl arasında kurulan ilișki örnek olarak verilebilir. Bu meselelerin aklî temelde izahı olmadığı gibi dini referanslardan bunu destekleyecek açık herhangi bir delil de yoktur. Yine bilgi kaynakları konusunda akıl, duyu ve haberin yanında iç duyulara, sezgiye ve hatâbeye yer vermeleri de onların epistemolojilerinin kesin bilgi oluşturduğuna yönelik bir eksikliktir. Ancak gerçek bu olmasına rağmen filozoflar akılcı, kelâmcılar nakilci oldukları ithamına maruz kalmışlardır. Oysaki kelâmcıların izahları ve delilleri dini referansların belirlediği naslar çerçevesinde şekillenirken aklî temelde izah edilmektedir. Akıl ve nakil karşıtlığından ziyade onların uyumundan bahseden ve nassı akılla çelişmeyen bir bilgi kaynağı olarak esas alan kelâmcılar daha yalın, makul ve kabul edilebilir bir itikattan bahsederken filozoflar ise ilkeleri muğlak bir itikattan, kurgusal yönü daha güçlü olan bir ulûhiyetten bahsederler. İlahi sıfatlar ile fiillerin keyfiyetine dair soyut bir çerçevede gelgitler yaşamaktadır. İlahi iradeden vazgeçmedikleri gibi ilahi iradenin zorunlu oluşunu ve tek taraflı işlev gördüğünü temellendirmeye gayret ederler.

Sûfîlerin bu konuda yaptıkları eleştiriye kısaca değinirsek; onlar ilim ile marifet kavramlarının arasını ayırmış, marifeti; eşyanın bâtınını ve iç yüzünü keşfetmekle elde edilen bilgi, ilmi ise; eşyanın zahiri ile ilgili elde edilen bilgi şeklinde değerlendirmişler. ${ }^{91}$ Onlara göre kelâmcıların bilgi kaynakları eşyanın zahiri bilgisini elde etme aracıdır. Oysa marifet ehli olan sûfîler ise hakikatin bilgisini mükâşefeyle elde etmekle uğraşırlar. Müteahhirûn dönemiyle birlikte kelâmcılar hem felsefî hem de tasavvufî epistemolojiden etkilenmişlerdir. Nasların zahiri manalarının yanında bâtınî manalarının bulunduğuna olan inancın kabul görmesi de mütekaddimûn dönemi kelâmcılarında net olan epistemik kaynakların esnetilmesine imkân vermiştir. Müteahhirûn dönemi epistemolojisinde zannîlik yönleri olan hadsiyyat, keşf, ilham, rüya ve sezgi gibi kavramlar kendilerine daha çok yer bulmuşlardır. Mütekaddimûn ve Müteahhirûn dönemlerinin kavşağında yer alan Gazzâlî̀nin dini inancın teşekkülünde mükâş̧efe ilmine önemli bir paye vermesi ve hakikatin idrakinde mutasavvifların yöntemlerinin ve bilgi kaynaklarının daha doğru ve sonucu götürdüğünü ifade etmesi ${ }^{92}$ kelâmî epistemolojinin de kurucu ilkelerinin esnetilmesine yol açmıştır. Mistik tecrübe ile ulaşılan ledünni bilgi Gazzâlî ile beraber kelâmî literatürde kendisine yer bulmuştur. Sözgelimi Gazzâlî kader ve ruhla ilgili bazı sırların ancak mana âleminde belli bir rusuha ulaşmış veliler ve ariflerin anlayabileceğini ifade etmektedir. ${ }^{93}$ Bu yaklaşım daha sonraki kelâmcılarda açıkça görülmektedir.

90 Öncülleri zanniyyât ve makbûlâttan oluşan kıyas.

91 Kelâbâzî, Doğuş Devrinde Tasavvuf Ta'arruf (İstanbul: Dergâh Yayınları, 1992), 97-98.

92 Ebu Hamid Gazzâlî, el-Munkızu mina'd-dalâl (Beyrut: el-Mektebetü'l-Asriyye, 2009), 65-67.

93 Ebu Hamid Gazzâlî, İhyâu ulûmi'd-din (Beyrut: Daru'l-Ma'rife, ts), 1/54; Süleyman Uludağ, "Bâtın İlmi”, İslam Ansiklopedisi (İstanbul: Türkiye Diyanet Vakfi, 1992), 5/188. 
Gazzâlî'den sonra felsefi kelâmın en güçlü mümessillerinden olan Fahreddin Râzî, ilhamı kelâmî epistemolojideki bilgi kaynakları içinde saymasa da riyazet ehli insanların ilham ve mükâşefe üzerinden bazı bilgilere erişebileceğini ancak bunların nazar ile sağlanmasının gerektiğine vurgu yapmaktadır. ${ }^{94}$ Teftâzâni, ilhamın bireysel anlamda bilgi kaynağı olabileceği gibi bağlayıc1 da olabileceğini kabul etmektedir. Ancak yine o, ilhamın insanların geneli için bilgi aracı olmadığına ve ilhamla sabit olan bilginin bağlayıcı kabul edilmediğine vurgu yapmaktadır. ${ }^{95}$ Bütün bu eleştirilerden dolayı meydana gelem kırılma sonucunda bazı kelâmcılar zannî bilgi ifade eden âhâd haber, ilham, hads, vicdan gibi kaynaklara atıfta bulunmuşlardır.

Zannın itikatta bilgi değeri konusunda açık bir şekilde kelâmî literatürde farklı bir söyleme sahip olan kişi Kemaleddin İbnü'l-Hümam'dır (ö.861/1457). O, kelâmın tanımını yaparken bazı konuların zannî bilgi ile delillendirildiğini açıkça ifade etmektedir. Bir başka deyişle İbnü’lHümam diğer kelâmcıların aksine zannın itikadın teşekkülündeki işlevine daha açık bir rol biçmiştir. Ona göre kelâm; bilgi ve bazı konularda zannî delilden hareketle kişinin aleyhine olan İslam dinine ait akîdeleri bilmesidir. İbnüll-Hümam'a göre Allah'ı ve O'nun zati sıfatlarını bilmek kesin bilgi ile belirlenirken peygamberliğin bazı şartları, maddumun iade edilmesinin keyfiyeti (dirilişin keyfiyeti) ve kabirde sorgu gibi meseleler ise zan ile bilinebilir. ${ }^{96}$

Yine kelâmda tartışma konusu olan imamet meselesi ne aklî açıdan burhana ne de kesinlik ifade eden nakle dayandırılmaktadır. Fahreddin Râzî, Şî’'nın imamet anlayışını eleștirerek bunun burhana veya kesinlik ifade eden nakle değil, zan ile olduğunu ifade etmiştir. 0 , imamın belirlenmesi ve atanmasında delilinin burhan değil, amel etmeyi gerekli kılan zan olduğunu ve bu zannında bilgi konumunda olmasından bizim için bağlayıcı olduğunu ifade etmektedir. Şayet imamın tayini Allah tarafından olsaydı, bu durumda zan değil kat' î bir burhan gerekirdi. ${ }^{97}$

Kelâm ilminin temel gayesi; ele aldığı itikadî konuları yakīni delillerle ispatlamak olmakla birlikte, bütün bu konuların sübût ve delâlet açısından kesinlik içeren delillerle temellendirilmesi mümkün gözükmemektedir. Tevhid, nübüvvet ve ahiret inancının temellendirilmesi için gereken kesin deliller ve bilgiler ile peygamberin sıfatları, miraç, kabir hayatı veya mehdinin gelişine olan inanç için getirilen delillerin aynı derecede kesinlik içermediği bedaheten bilinmektedir.

Selefi ve zahiri âlimler âhâd haberin hem amel de hem de itikatta delil oluşunun gerekliliğini açıkça savunmuşlardır. Onlara göre mizan, sırat, şefaat, havz, kabir azabı, cennet ve cehennem ehlinin ahvali gibi birçok inanç konusu ancak âhâd haber ile temellendirilebilir. Kelâmcılar da teoride itikadî konularda zannî delillerin kesin bilgi ifade etmeyeceği için delil olamayacağını ifade etmişlerse de bu tür zannî delilleri birçok itikadî hususun kabul edilmesinde ya asli ya da tali derecede kullanmışlardır. Ehl-i sünnet kelâmcılarının çoğunun eserlerinde sem‘iyyâta ilişkin konularda; nübüvvet, diriliş, rü’yetullah, deccal, kıyamet alametleri, İsa veya Mehdi'nin gelişi

94 Fahreddin Muhammed b. Ömer er-Râzî, el-Metâlibu'l-'aliyye mine'l-ilmi'l-ilahi, thk. Ahmed Hicâzî es-Sekâ (Beyrut: Daru'l-Kitabi'l-Arabi, 1987), 1/58.

95 Bk. Teftâzânî, Şerhu'l-Akāid, 96.

96 Kemâl İbnü'l-Hümâm, el-Müsâyere fì ilmi'l-kelam ve'l-akāidi't-tevhidiyyeti'l-münciyye fi'l-ahire (Kahire: el-Matbaatü'lMahmûdiyyeti't-Ticâriyye, ts.), 5.

97 Râzî, Me'âlimü usûli'd-dîn, 256-258. 
gibi konularda zannî olduğunu kabul ettikleri rivayetleri esas aldıkları görülmektedir. ${ }^{98}$ Bunun yanı sıra Kādî Abdulcebbâr gibi bazı Mu'tezilî âlimler de kabir azabını kabul etmekte ve bu konuda zannî olarak kabul ettikleri rivayetleri kendi itikadî tutumlarını desteklemek için kullanmışlardır.99

Naklî deliller sübût veya delâlet açısından kesinlik taşımayabilirler. Nasların taşıdığı dilsel özellikler ve onları anlamaya ve yorumlamaya tabi tutan insanın taşıdığı özellikler birlikte dikkate alındığında bunun doğal bir durum olduğu görülür. En nihayetinde aklî ya da naklî bazı delillere dayandırılan inanç, inananların varlık ve epistemoloji anlayışlarına bağlı olarak teşekkül edecektir. Çünkü her bir itikad, bir anlamlandırma ameliyesi üzerine yapılan duyusal ve zihinsel bir kabul ve inşadır. Dolayısıyla ekollerin dîni telakkileri, onların varlık, bilgi, insan ve hayat anlayışlarından bağımsız teşekkül etmez. Nitekim buna bağlı olarak kelâmî ekollerin ve düşünürlerin farklı itikadî tutumlar sergilemeleri de anlaşılabilir.

\section{Sonuç}

İnanç en nihayetinde epistemik ve duygu yönü oldukça güçlü olan bir kanaattir. Kanaat ise zandan hareketle oluşturulmuş veya güçlü zanna dayanan bir inanmadır. Bir başka deyişle inanç, yakīni bilgiye oldukça yakın olan ancak yanılma ihtimali akla getirilemeyen bir zandır. Dolayısıyla zan-itikat ve ilim kavramlarının birbirleriyle yakın ve geçişken bir ilişkisi söz konusudur. Bu nedenle bu kavramlar arasındaki ilişkiyi keskin söylemlerle birbirinden ayırmak kolaycı bir yaklaşım olur.

İslam düşünce geleneğinde zannî bilginin kurucu bir epistemik role ve değere sahip olduğu genel kabul gören bir görüştür. Ancak bu görüş inanç konularının belirlenmesi ve temellendirilmesi konusunda farklı görüş ve tartışmaları doğurmuştur. Kelâmi epistemolojide inanç konularının belirlenmesi ve temellendirmesinde yakīn ifade eden bilginin esas alınması oldukça önemsenmiş, bu konuda kesin bir söylem oluşturulmuştur. Kelâmcıların, itikadın kesinlik ifade eden istidlal yöntemleri ve bilgi türlerine dayanmasını gerekli ve/veya zorunlu görmeleri, itikadın, dinin temelini ve omurgasını oluşturduğu düşünüldüğünde oldukça değerlidir. Bu ilkesel tutuma rağmen zannî bilginin inanç konularını belirleme, gerekçelendirme ve savunmada kullanıldığı da görülmektedir. Müslüman düşünürler arasında hangi aklî ve naklî bilgilerin kesinlik veya zan ifade ettiği konusunda bir fikir birliği olmadığı için her biri bazen aynı bazen de farklı yöntem ve bilgilerle inanç konularını temellendirme yoluna gitmiştir. İnanma hadisesi, en nihayetinde kişinin ikna edilmesine dayanmakta; ikna edilme de kişiden kişiye değişebildiği gibi konudan konuya da farklılık arz edebilmektedir. Kelâmî ekollerin temel doktrinlerini temellendirme kaygısı ve öncelikleri, onların kesinlik ve zan içeren farklı delil ve bilgi türlerine yaklaşımlarında etkili olmuştur.

Kelâmî epistemolojide genel olarak yakīni bilgi; aklî veya naklî delil aracilığıyla mümkün görülmüştür. Kesinlik ancak aklî istidlalde bulunulurken kişinin zorunlu olarak ulaştı̆̆1 sonuç üzerinde zihnin ve gönlün vakıaya uygunluğu ve değişmezliği konusunda bir zan, şek ve vehim taşımaması durumunda söz konusudur. Kesinlik sağlayan aklî deliller, mantık ilkelerine uygun işleyen akıl (sahih nazar) ve sağlam duyu aracıllğıyla gerçekleşebilir. Bazı aklî istidlaller bu

98 Tuğlu, “İmâm Mâturîdı̂’de Haber-i Vahidlerin Değeri”, 9.

99 Kādî Abdülcebbâr, Şerhu'l-Usûli'l-hamse, 730-731. 
kesinliği sağlamamış ve zannî bilgi kategorisinde kullanılmıştır. Zannî bilgi ifade eden aklî istidlaller de tıpkı zannîlik ifade eden âhâd haber gibi bağlayıcı kabul edilmemiştir. Kelamî ekoller arasında aynı inanç konularında görülen farklılıkların önemli bir nedeni, aklî ve naklî delillere yüklenilen kesinlik değerinin göreceliğidir.

Kelâmcılar ilkesel olarak itikadî ilkelerin dayandıııldığı naklî bilginin bağlayıcı olabilmesi için hem sübûtu/kaynağı hem de delâleti/ifade ettiği mana açısından kesinlik ifade etmesini zorunlu görmüşlerdir. Ancak bazı naklî deliller ya sübût ya da delâlet açısından bu kesinliği sağlayamayabilir. Naklî bilgiyi, haber olması cihetiyle zan kategorisinde gören mantıkçılara karşı kelâmcllar mütevatîr haberin yakin bilgi ifade ettiğini savunmuş ve akidenin belirlenmesinde bağlayıcı olduğunu savunmuşlardır. Hatta tali inanç diyebileceğimiz bazı sem'iyyât konularında zan kategorisinde görülen âhâd haberlerin kullanıldığı vakidir. Kelâmcılar tarafından sıklıkla dile getirilen naklî bilginin bağlayıcı delil statüsünde olabilmesi için sübût ve delâlet yönünden kesinliğinin gerekliliği, bazen sübût bazen de delâlet yönünden tartışılmış, ekoller tarafından farklı değerlendirilmiştir. Dolayısıyla naklî bilginin zannîlik boyutu ya aktarıcılar ya da lafızların delâlet ettiği mana itibariyle bir şekilde var olduğu gözden ırak tutulmalıdır.

Kelâmcılar, kaynağı itibariyle sabit olmayan bir haberi veya farklı tevillere imkân veren bir metni esas alarak kendi görüşlerini tesis etmişlerse de birbirlerinin inançları hakkında kesin yargılarda bulunmaktan ve keskin söylemlerden kaçınmışlardır. Kelâmcılara göre delâlet açısından kesinlik sağlamayan bir haberin veya hükmün kabul edilmemesinin küfrü gerektirmemesi oldukça önemli bir yaklaşımdır. Bu yaklaşım nedeniyle ekoller veya kelâmcılar geçerli kabul ettikleri istidlal yöntemlerine dayanarak diğer ekolleri veya kelâmcıları eleştirmiş ve yermişler; ancak tekfirden kaçınmışlardır. Kendi görüşlerini destekleyen zannî delilleri özellikle sem'iyyât bahislerinde kullanmışlardır. Kelâmcılar kesinlik sağlamayan aklî bilgi türlerine, itikatta kurucu bir rol vermemiş olmakla beraber muhataplarını, muarızlarını veya müntesiplerini ikna etmek veya ilzâm etmek için kullanmışlardır. 


\section{Kaynakça}

Al-Omarî, Ali Mahmood - Kutlu, Hakan. "Müteahhirûn Kelâmında Kullanılan İstidlâl Metotları". Kocaeli İlahiyat Dergisi 3/2 (28 Aralık 2019), 125-144.

Altıntaş, Ramazan. "Kelami Epistemolojide Aklın Değeri”. Cumhuriyet Üniversitesi İlahiyat Fakültesi Dergisi 5/2 (15 Aralık 2001), 97-130.

Âmidî, Seyfuddin. Ebkârü'l-efkâr. ed. Ahmed Ferid Mezidi. Beyrut: Daru'l-Kutubü'l-i̇lmiyye, 2003.

Bâkıllânî, Ebû Bekr Muhammed b. Tayyib b. Muhammed el-Basrî. et-Takrîb ve'l-irşâdü's-sağîr. thk. Abdulhamit b. Ali Ebû Zeyd. Lübnan: Müessesetü’r-Risâle, 1998.

Beroje, Sahip. "Zannî Bilginin Mahiyeti, Dindeki Yeri ve Önemi”. Şarkiyat 9/2 (30 Kasım 2017), 951-974.

Cürcâni, Seyyid Şerif. Kitabü't-Ta'rîfât. thk. Muhammed Abdurrahman el-Mer'aşlî. Beyrut: Daru'n-Nefâis, 2007.

Cürcânî, Seyyid Şerîf. Şerhu'l-Mevâkıf. İstanbul: Türkiye Yazma Eserler Kurumu Başkanllğı, 2015.

Cüveynî, İmâmü'l-Haremeyn Ebü'l-Meâlî Rüknüddîn Abdülmelik b Abdullâh b Yûsuf. el-İrşâd ila kavâtii'l-edilleti fî usûli'l-i'tikād. Kahire: Mektebetü'l-Hanci, 1950.

Çağlayan, Harun. Kelam'da Bilgi Kaynakları. Ankara: Ankara Üniversitesi / Sosyal Bilimler Enstitüsü /, Doktora, 2009.

Çağrıc1, Mustafa. "Zanniyat". 44/123-124. İstanbul: Türkiye Diyanet Vakf1 İslâm Ansiklopedisi, 2013.

Demir, Osman. "Yakîn”. C. 43. İstanbul: Türkiye Diyanet Vakf1 İslâm Ansiklopedisi, 2013.

Erdemci, Cemalettin. "Kelam İlminde Haberin Epistemolojik Değeri". Dinbilimleri Akademik Araştırma Dergisi 6/4 (01 Ağustos 2006), 153-176.

Garib, Ahmed Adil el-. Tesbîtu hücciyyeti haberi'l-vâhid. yy: Merkezu Tefekkür li'l-Buhus ve'dDirasat, 2016.

Garsî, Muhammed Salih b Ahmed. Menhecü'l-Eş'aireti fi'l-akīde beyne'l-hakāik ve'l-evhâm. İstanbul: Ravza Yayınları, 2006.

Gazzâlî, Ebu Hamid. el-Munkızu mina'd-dalâl. Beyrut: el-Mektebetü'l-Asriyye, 2009.

Gazzâlî, Ebu Hamid. İhyâu ulûmi'd-din. 4 Cilt. Beyrut: Daru'l-Ma'rife, ts.

Gazzâlî, Ebu Hamid. Mustasfa. çev. Yunus Apaydın. 2 Cilt. Kayseri: Rey Yayıncllık, 1994.

Gazzâlî, Ebû Hamid Muhammed b Muhammed. el-Mustesfa min ilmi'l-usul. thk. Muhammed Yusuf Necm. Beyrut: Dâru Sadr, 2010.

Harman, Vezir. "Seyfeddin Amidî’nin Kelam Sisteminde Kat'ilik ve Zannilik Açısından Deliller". KADER Kelam Araştırmaları Dergisi 10/2 (15 Temmuz 2012), 129-146. 
Hın, M. Muaz Mustafa el-. el-Kat'î ve'z-zannî fi's-sübût ve'd-delâle 'inde'l-usûliyyîn. Dımaşk: Darü'l-Kelimi't-Tayyib, 2007.

İbn Haldun, Abdurrahman b. Muhammed. Mukaddimetü İbn Haldun. thk. Seyyid Mahmud Ukeyyil. Beyrut: Daru'l-Ĉ̂l, 2013.

İbnü'l-Hümâm, Kemâl. el-Müsâyere fî ilmi'l-kelam ve'l-akāidi't-tevhidiyyeti'l-münciyye fi'lahire. Kahire: el-Matbaatü'l-Mahmûdiyyeti't-Ticâriyye, ts.

Îcî, Ebü'l-Fazl Adudüddin Abdurrahman b Ahmed b Abdülgaffar. Kitâbü'l-Mevakıf. Beyrut: Dârü'l-Cil, 1997.

İsfahânî, Ragıp el-. el-Müfredât fî elfâzi'l-Kur'an. ed. Safvan Adnan Davûdi. Dımaşk: Darü'l-Kalem, 4. Basim, 2009.

Kādî Abdülcebbâr. Şerhu'l-Usûli'l-hamse. thk. Abdülkerim Osman. Kahire: Mektebetü Vehbe, 4. Basım, 2006.

Kelâbâzî. Doğuş Devrinde Tasavvuf Ta'arruf. İstanbul: Dergâh Yayınları, 2. Basım, 1992.

Korkmazgöz, Rıza. "Kelam İlminde Haber-i Vâhidin Bilgi ve Delil Değeri”. Dinbilimleri Akademik Araştırma Dergisi 18/1 (31 Mayıs 2018), 225-258.

Melâhimî, Mahmud İbn Muhammed. Kitâbü'l-mu'temed fî usûli'd-dîn. thk. Wilferd Madelung. Tahran: Muessesatü mütal'âti İslami Danişgâhi Âzadi İslami Berlin, İlaveli Baskı., 2012.

Memiş, Murat. Kâdı Abdülcebbâr'da Bilgi Problemi. İzmir: Dokuz Eylül Üniversitesi / Sosyal Bilimler Enstitüsü, Doktora, 2007.

Nesefi, Ebu'l-Muin Meymun b Muhammed en-. Tebsıratü'l-edille fî usûli'd-dîn. thk. Hüseyin Atay. Ankara: Diyanet İşleri Başkanlığı, 2004.

Özdemir, Metin. "Kelâmî İstidlâlin Problematiği". Cumhuriyet Üniversitesi İlahiyat Fakültesi Dergisi 5/2 (2001), 176-201. https://dergipark.org.tr/tr/pub/cuifd/issue/4307/257225

Quin, V. W. - Ullian, J. S. Bilgi Ağı. çev. Hadi Adanalı. Ankara: Kitabiyat, 2001.

Quin, V. W. - Ullian, J. S. The Web of Belief. Newyork: McGraw-Hill Education, 1978.

Râzî, Fahreddin Muhammed b. Ömer er-. el-Mahsûl. thk. Taha Cabir Feyad el-Alvânî. Müessesetü’r-Risâle, 3. Basım, 1997.

Râzî, Fahreddin Muhammed b. Ömer er-. el-Metâlibu'l-'aliyye mine'l-ilmi'l-ilahi. thk. Ahmed Hicâzî es-Sekâ. Beyrut: Daru'l-Kitabi'l-Arabi, 1987.

Râzî, Fahreddin Muhammed b. Ömer er-. et-Tefsirü'l-Kebîr. Kahire: Daru'l-hadîs, 2012.

Râzî, Fahreddin Muhammed b. Ömer er-. Me'âlimü usûli'd-dîn: Kelâm İlminin Esasları. çev. Muhammet Altaytaş. İstanbul: Türkiye Yazma Eserler Kurumu Başkanlığı, 2019.

Râzî, Muhammed b Ömer b Hüseyin Fahreddin. Kelam'a Giriş: (el-Muhassal). Ankara : Kültür Bakanlı̆̆ı, 2002. 
Sübkî, Tâceddin Abdulvehhâb b. Ali. Cem'u'l-cevâmi'. Beyrut: Daru'l-Kütübi'l-ilmiyye, 2. Basım, 2003.

Şahin, Hüseyin. "Kelamcılara Göre Delil ve Delil Türleri". KADER Kelam Araştırmaları Dergisi 13/1 (13 Şubat 2015), 453-472.

Teftâzânî, Sa'deddîn et-. el-Makāsıd. çev. İrfan Eyibil. İstanbul: Türkiye Yazma Eserler Kurumu Başkanlı̆̆ı, 2019.

Teftâzânî, Sa 'deddîn et-. Şerhu'l-Makāsıd. Lübnan: Darü'l-Kütübi'l-i̇lmiyye, 2. Basım, 2011.

Teftâzânî, Sa'düddîn et-. Şerhu'l-Akāid. çev. Talha Hakan Alp. İstanbul: İFAV, 3. Basım, 2017.

Tuğlu, Nuri. “İmâm Mâturîlî'de Haber-i Vahidlerin Değeri”. Uluğ Bir Çınar: İmâm Mâturîdî: Uluslararası Sempozyum Tebliğler Kitabı. 583-588. Eskişehir, 2014.

Uludağ, Süleyman. "Bâtın İlmi”. İslam Ansiklopedisi. 5/188-189. İstanbul: Türkiye Diyanet Vakfı, 1992.

Yılmaz, Mustafa Selim. "Kelâm İlminde Mütevâtir Haberin Bilgi ve Delil Değeri”. Dinbilimleri Akademik Araştırma Dergisi 18/1 (2018), 199-223.

Zelmî, Mustafa İbrahim ez-. el-Mantıku'l-kânûnî fi't-tasavvurât. yy: yy, 1. Basım, 2011.

Zerkeşî,, Bedreddin ez-. Luktatü'l-'aclân. thk. Muhammed Cemaleddin el-Kasimi ed-Dımeșkî. Kahire: Medresetü Valideti Abbasi'l-Evvel, 1908.

Zevahiri, Muhammed Hüseyni ez-. Tahkîkü't-tâm fî ilmi'l-kelâm. Kahire: Mektebetü'l-Hicazi, 1939. 